\title{
African Disunity: Comparing Human Rights Law and Practice of North and South African States ${ }^{1}$
}

\author{
Jean Allain* \& Andreas $O^{\prime}$ Shea**
}

\section{INTRODUCTION}

Within the domain of respect for human and peoples' rights by African states there has been, until recently, little unity of purpose. The common standards that African states have maintained in their laws and practices regarding human rights have been their willingness to subscribe formally to international and regional norms, while at the same time, to violate those undertakings with near impunity. When the Protocol to the African Charter on the Establishment of the African Court on Human and Peoples' Rights (Protocol) comes into force, ${ }^{2}$ it will provide for an African court having the responsibility to hold states to their obligations and to establish continent-

* Jean Allain is Assistant Professor of Public International Law, Department of Political Science, The American University in Cairo, Egypt.

** Andreas $O^{\prime}$ Shea is Senior Lecturer at the University of Durban-Westville, South Africa.

1. This article is dedicated to the family and memory of the late Michael M. Makhabane. Michael was a student of public administration who was shot dead by police on 16 May 2000 just meters away from the Oliver Tambo Building on the campus of the University of Durban Westville.

2. For the African Commission on Human and People's Rights consideration of the draft Protocol to the African Charter on Human and People's Rights on the Establishment of an African Court of Human and People's Rights, see Resolution on the African Commission on Human and Peoples' Rights, 64th Session of the Council of Ministers of the Organization of African Unity, 1-5 July 1996, Yaoundé, Cameroon, OAU/LEG/MIN/ AFCHPR/PROT.1 rev.2 (1997).

While fifty-three states have signed the Protocol, as of February 2001, four states, (Burkina Faso, Gambia, Mali and Senegal) out of fifteen states required have ratified or acceded. See Status of Ratification of the Protocol to the African Charter on Human and Peoples' Rights on the Establishment of an African Court on Human and Peoples' Rights, available at $<$ http://www.up.ac.za/chr/ahrdb/statorat_13.html > . 
wide standards. ${ }^{3}$ Thus, within the domain of human rights, the states will take a step closer to realizing common norms worthy of a continent which has, as its fundamental underpinning and ethos, the notion of African unity.

The establishment of a human rights regime in Africa is manifest in the African Charter on Human and People's Rights of 1981 (African Charter). ${ }^{4}$ African states passed this Charter under the auspices of the Organization of African Unity (OAU), which represents an effort on the part of African states to unite in the promotion of human and peoples' rights. Indeed, the Preamble to the founding instrument of the OAU expresses the desire "that all African States should henceforth unite so that the welfare and well-being of their peoples can be assured." ${ }^{5}$ By accepting this Protocol to the African Charter, the Council of Ministers of the OAU has signaled that states are ready to go beyond the African Commission framework, ${ }^{6}$ established by the OAU founding treaty, to a system of obligatory judgments and sanctions. ${ }^{7}$

In this interim period, between the acceptance of the Protocol in principle by the OAU, which was achieved in 1996, and the arduous process of seeking state ratification, continuous emphasis must be placed on the need for the establishment of the African Court on Human and Peoples' Rights (African Court), which could assist states in determining norms applicable to the African experience as a whole. The following study demonstrates to what extent the current state of the law and practice on the northern and southern portions of the continent are at odds with this sentiment, being akin to African disunity. Consideration is given to human rights application, with a view to shedding light on the extent to which Africa lacks a unified approach to human rights protection. The selected sample will be confined to members of the OAU which form the poles of

3. See Protocol to the African Charter on Human and People's Rights on the Establishment of an African Court on Human and Peoples' Rights, OAU/LEG/EXP/AFCHPR/PROT III, adopted at the 36th Ordinary Session of the Assembly of the Heads of State and Government of the OAU, Ouagadougou, Burkina Faso, on 9 June 1998, reprinted in 6 INT'L Hum. RTs. Rep. 891, available on <http://www.up.ac.za/chr/ahrdb/treaties4.html>.

4. The African Charter, commonly referred to as the "Banjul Charter," was adopted in the Gambian capital in 1981 "by the Eighteenth Assembly of the Heads of States and Government of the Organization of African Unity." See African Charter on Human and Peoples' Rights, art 30, adopted 27 June 1981, O.A.U. Doc. CAB/LEG/67/3 Rev. 5 (entered into force 21 Oct. 1986), reprinted in 21 I.L.M. 58 (1982), available at <http:// www.itcilo.it/english/actrav/telearn/global/ilo/law/africahr.htm> [hereinafter African Charter].

5. Charter of the Organization of African Unity, 479 U.N.T.S. 39, entered into force 13 Sept. 1963, available at <http://www1.umn.edu/humanrts/africa/OAU_Charter_1993. html>.

6. See African Charter, supra note 4. Article 30 of the African Charter on Human and People's Rights created an African Commission within the OAU to promote human rights. Id.

7. See id. 
the African continental land mass. From northern Africa, this study will consider Algeria, Egypt, Libya, and Tunisia but excludes Morocco. ${ }^{8}$ The analysis incorporates Angola, Botswana, Lesotho, Malawi, Namibia, South Africa, Swaziland, Zambia, and Zimbabwe from the southern region. ${ }^{9}$

Both of these groups consist of states in close geographical proximity that have commonalties with their immediate neighbors. Certain features can instantly be identified as common to both groups of states, including a colonial history, large-scale poverty, and short periods of time since independence. However, as this study will demonstrate, what differentiates these states, primarily cultural norms, is most significant when the application of human rights law is at play. While an examination of Western and Eastern Africa would provide various nuanced differences in human rights law and its applications, by focusing on the other axis, this study seeks to demonstrate where the gap in the subscription to and application of human rights is most obvious. Through an analysis of treaty obligations, the extent to which human rights have been incorporated in the respective constitutions, and finally, the human rights situations in each state under review, this article considers the extent to which the approach to human rights in the two regions contradicts or alternatively bears out African unity.

\section{TREATY OBLIGATIONS}

\section{A. North African States}

North African states are party to the most important human rights treaties. From a formalistic standpoint, therefore, North African states have, by and large, accepted international human rights law. Thus, Algeria, Egypt, Libya, and Tunisia have all embraced the principal human rights treaties developed under the auspices of the United Nations. These instruments include the 1948 Convention on the Prevention and Punishment of the Crime of Genocide (Genocide Convention), ${ }^{10}$ the 1966 International Convention on

8. Morocco left the O.A.U. in 1984 as a result of the organization's recognition of representatives of the people of Western Sahara. See Frans Vijoen, Overview of the African Regional Human Rights System, in 1999 Human Rights Law in Africa Series 129 (Christof Heyns ed., 2001).

9. For the duration of the article, "North Africa" or "North" will refer to the northern African states included in the analysis, and "Southern Africa" or "Southern" will refer to the southern African states.

10. See Convention on the Prevention and Punishment of the Crime of Genocide, adopted 9 Dec. 1948, G.A. Res. 260 A (III), 78 U.N.T.S. 277 (entered into force 12 Jan. 1951), available at <http://www.unhchr.ch/html/menu3/b/p_genoci.htm> [herinafter Genocide Convention]. 
the Elimination of all Forms of Racial Discrimination (Racial Discrimination Convention), ${ }^{11}$ the 1966 International Covenant on Economic, Social and Cultural Rights (ICESCR), ${ }^{12}$ the 1966 International Covenant on Civil and Political Rights (ICCPR), ${ }^{13}$ and the 1984 Convention against Torture and Other Cruel, Inhuman or Degrading Treatment or Punishment. ${ }^{14}$ This formal

Information regarding participants to this and other treaties can also be located in United Nations, Multilateral Treaties Deposited with the Secretary-General 98, 98-114 (1999) (status as of $30 \mathrm{Apr}$. 1999) [hereinafter Multilateral Treaties]. Current signature, ratification, and reservation status is also available at $<\mathrm{http}: / /$ www.unhchr.ch $/ \mathrm{html} / \mathrm{menu} / \mathrm{b} /$ treaty1gen.htm>."

Please note that the United Nations Treaty Series website currently charges a fee of US \$250 for access from the Continent, which makes access inaccessible to all but a handful of institutions in Africa. See Philip Alston, Charging for Access to International Law Treaty Information: Time to Rethink a Perverse Initiative, 12 Eur. J. INT'L. L., 351, 358 (2001) (for additional information about this fee). Comments on this policy may be forwarded to treaty@un.org.

11. See International Convention the Elimination of All Forms of Racial Discrimination, adopted 21 Dec. 1965, G.A. Res. 2106 (XX),660 U.N.T.S. 195 (entered into force 4 Jan. 1969), available at <http://www.unhchr.ch/html/menu3/b/d_icerd.htm> [herinafter Racial Discrimination Convention]. Information on signature, ratification, and reservation status is available in Multilateral Treaties, supra note 10, at 98. Current status information is also available at <http://untreaty.un.org/ENGLISH/bible/englishinternetbible/partl/ chapterlV/treaty2.asp $>$.

Algeria has made a declaration to the effect that it recognizes the competence of the Committee on the Elimination of Racial Discrimination to consider individual and group petitions claiming violations of the Convention. See Multilateral Treaties, supra note 10, at 110 .

12. See International Covenant on Economic, Social and Cultural Rights, adopted 16 Dec. 1966, G.A. Res. 2200A (XXI),993 U.N.T.S. 3 (entered into force 3 Jan. 1976), available at <http://www.unhchr.ch/html/menu3/b/a_cescr.htm> [hereinafter ICESR]. Information on signature, ratification, and reservation status is available in Multilateral Treaties), supra note 10, at 115. Current status information is also available at $<\mathrm{http}: / /$ untreaty.un.org/ ENGLISH/bible/englishinternetbible/partl/chapterlV/treaty4.asp >.

13. See International Covenant on Civil and Political Rights, adopted 16 Dec. 1966, G.A. Res. 2200A (XXI), 999 U.N.T.S. 171 and 1057 U.N.T.S. 407 (entered into force 23 March 1976 for all provisions except those of Article 41; 28 March 1978 for the provisions of Article 41), available at <http://www.unhchr.ch/html/menu3/b/a_ccpr.htm> [hereinafter ICCPR]. Information on signature, ratification, and reservation status is available in Multilateral Treaties, supra note 10, at 128. Current status information is also available in <http://untreaty.un.org/ENGLISH/bible/englishinternetbible/partl/chapterIV/ treaty5.asp $>$

Note that both Algeria and Tunisia have made declarations under Article 41 recognizing the competence of the Human Rights Committee "to receive and consider communications to the effect that a State Party claims that another State Party is not fulfilling its obligations under the present Covenant." Multilateral Treaties, supra note 10, at $143-46$.

14. See Convention against Torture and Other Cruel, Inhuman or Degrading Treatment or Punishment, adopted 26 Nov. 1987, G.A. Res. 39/46, 1465 U.N.T.S. 85 (entered into force 26 June 1987), available at <http://www.unhchr.ch/html/menu3/b/h_cat39.htm> [hereinafter Torture Convention]. Information on signature, ratification, and reservation status is available in a Multilateral Treaties, supra note 10, at 201. Current status information is also available at $<$ http://untreaty.un.org/ENGLISH/bible/englishinternetbible/ partl/chapterIV/treaty12.asp $>$. 
acceptance of human rights treaties is also manifest at the regional level where the four states have ratified both the African Charter and the OAU Convention Governing the Specific Aspects of Refugee Problems in Africa. ${ }^{15}$

Yet ratification may not, by itself, settle a state's international obligations. These states have made use of reservations that have significantly narrowed the extent of their obligations. Furthermore, in Algeria and Egypt, extended states of emergency have allowed these states to derogate from a significant number of obligations in terms of the ICCPR.

So, while accepting the norms embodied in human rights conventions in principle, the reservations the northern states have made have excluded them from the obligations regarding binding procedures for settling disputes over the application or interpretation of the very same treaties. Illustrative of this phenomenon is Algeria's relationship toward the Genocide Convention when, in acceding to it in 1963, it formulated the following reservation: "The Democratic and Popular Republic of Algeria does not consider itself bound by article IX of the Convention, which confers on the International Court of Justice jurisdiction in all disputes relating to the said Convention."16

Similarly, both Egypt and Libya have made substantively the same reservation to the Racial Discrimination Convention. ${ }^{17}$ Likewise, Tunisia made such a reservation to the Convention on the Elimination of All Forms of Discrimination against Women (CEDAW) in which the country rejected the obligatory character of the dispute settlement procedures provided under the treaty. ${ }^{18}$

Here again, Algeria and Tunisia have made declarations recognizing the competence of a treaty body, the Committee against Torture, to consider communications much in the same vein as the Human Rights Committee. Further, both states "recognize the competence of Committee to receive and consider communications from or on behalf of individuals subject to its jurisdiction who claim to be victims of a violation" of the Convention. See Multilateral Treaties, supra note 10, at 205, 208. The text of Article 22, which governs declarations made under this treaty, is available at <http://www.unhchr.ch/ $\mathrm{html} / \mathrm{menu} 3 / \mathrm{b} / \mathrm{h} \_$cat39.htm $>$.

15. See 1997 Human Rights Law in Africa Series 6-7 (Christof Heyns ed., 1999).

16. Multilateral Treaties, supra note 10 , at 90.

17. See Multilateral Treaties, supra note 10, at 101-02. In acceding to the Racial Discrimination Convention in 1968, Libya followed the lead of Egypt in presenting a reservation which was, mutatis mutandis, the same as that found attached to Egypt's 1967 instrument of ratification:

The Kingdom of Libya does not consider itself bound by the provisions of article 22 of the Convention, under which any dispute between two or more States Parties with respect to the interpretation or application of the Convention is, at the request of any of the parties to the dispute, to be referred to the International Court of Justice for decision, and it states that, in each individual case, the consent of all parties to such a dispute is necessary for referring the dispute to the International Court of Justice.

Id. at 102 .

18. See Convention on the Elimination of All Forms of Discrimination against Women, adopted 18 Dec. 1979, G.A. Res. 34/180, 1249 U.N.T.S. 13 (entered into force 3 Sept. 1981) available at <http://www.unhchr.ch/html/menu3/b/e1cedaw.html> [hereinafter 
From the perspective of the African continent, the stance of the northern states regarding CEDAW, as reflected in their reservations, is unique. In line with other Middle Eastern and Muslim states, the North African states have subordinated their obligations in this area to the dictates of Shari'a law. For instance, Egypt has felt the need to bring regional norms in line with Shari'a law and subject its obligations to its domestic legislation as reflected in its reservation to the African Charter. ${ }^{19}$ Accordingly, Article 8 on freedom of conscience and Article 18(3) on ensuring the protection of women and children as well as non-discrimination, ${ }^{20}$ are to be "implemented in accordance with the Islamic Law." 21

Such limitations are also apparent from the reservations that Egypt, Libya, and Algeria have made to Article 2 of CEDAW, which outlines states' obligations with respect to eliminating discrimination against women. ${ }^{22}$

CEDAW]. Information on signature, ratification, and reservations status is available in Multilateral Treaties, supra note 10 , at 178 . Current status information is also available at <http://untreaty.un.org/ENGLISH/bible/englishinternetbible/partl/chapterIV/treaty9.asp>.

The reservation formulated by Tunisia when ratifying CEDAW 1985 reads in part:

The Tunisian government declares, in conformity with the requirements of article 29, paragraph 2 of the Convention, that it shall not be bound by the provisions of paragraph 1 of that article which specify that any dispute between two or more States Parties concerning the interpretation or application of the present Convention which is not settled by negotiation shall be referred to the International Court of Justice at the request of any one of those parties.

The Tunisian government considers that such disputes should be submitted for arbitration or consideration by the International Court of Justice only with the consent of all parties to the dispute.

Id. at 186 .

19. See supra note 15. The reservation of Egypt to the African Charter reads:

Having considered the African Charter on Human and Peoples' rights, the Arab Republic of Egypt signed the said Charter on 16 November 1981 and attached hereto is the following instrument of ratification:

Having accepted all the provisions of the African Charter on Human and Peoples' Rights with the approval of the People's Assembly and with the reservation that article 8 and paragraph 3 of article 8 be implements in accordance with Islamic Law and that, as far as the Arab Republic of Egypt is concerned, the provisions of the first paragraph of article 9 should be [confined] to such information as could be obtained within the limits of Egyptian laws and regulations;

We hereby declare acceptance and ratification of the said Charter.

Id. at 10 .

20. The text of Article 18(3) of the African Charter reads:

The state shall ensure the elimination of every discrimination against women and also ensure the protection of the rights of the women and the child as stipulated in international declarations and conventions.

African Charter, supra note 4.

21. See supra note 19 (for details of Egypt's reservation to the African Charter).

22. See Multilateral Treaties (CEDAW), supra note 10, at 178-99. Article 2 of CEDAW reads:

States Parties condemn discrimination against women in all its forms, agree to pursue by all appropriate means and without delay a policy of eliminating discrimination against women and, to this end, undertake:

(a) To embody the principle of the equality of men and women in their national constitutions or other appropriate legislation if not yet incorporated therein and to ensure, through law and other appropriate means, the practical realization of this principle; 
Egypt formulated its reservation regarding Article 2 in general terms by noting that it "is willing to comply with the content of this article, provided that such compliance does not run counter to Islamic Shari'a." ${ }^{23}$ Libya also couched its reservation in general terms, reformulating its original reservation to Article 2, which was more narrow in content, by declaring in 1995 that its "accession cannot conflict with the laws on personal status derived from the Islamic Shari'a." 24 Algeria accepts the dictates of Article 2 to the extent that they "do not conflict with the provisions of the Algerian Family Code," 25 which has codified Islamic norms.

While a prima facie consideration of reservations to CEDAW might lead one to believe that they give room for states to discriminate negatively against women, this outcome should not be assumed. Consider the Egyptian reservation to Article 16 of the CEDAW, dealing with marriage and family relations, that calls for a "just balance" between "an equivalency of rights and duties" of men and women. ${ }^{26}$ On the one hand, the reservation notes that:

provisions of the Shari'a lay down that the husband shall pay bridal money to the wife and maintain her fully and shall also make a payment to her upon divorce, whereas the wife retains full rights over her property and is not obliged to spend anything on her keep. ${ }^{27}$

Such measures clearly benefit women financially during marriage. However, in times of divorce the rub comes in the following sentence, where this

(b) To adopt appropriate legislative and other measures, including sanctions where appropriate, prohibiting all discrimination against women;

(c) To establish legal protection of the rights of women on an equal basis with men and to ensure through competent national tribunals and other public institutions the effective protection of women against any act of discrimination;

(d) To refrain from engaging in any act or practice of discrimination against women and to ensure that public authorities and institutions shall act in conformity with this obligation;

(e) To take all appropriate measures to eliminate discrimination against women by any person, organization or enterprise;

(f) To take all appropriate measures, including legislation, to modify or abolish existing laws, regulations, customs and practices which constitute discrimination against women;

(g) To repeal all national penal provisions which constitute discrimination against women.

CEDAW, supra note 18.

23. Multilateral Treaties, supra note 10 , at 181.

24. Id. at 183. Libya's original reservation read: "Article 2 of the Convention shall be implemented with due regard to the peremptory norms of Islamic Shariah relating to determination of inheritance portions of the estate of a deceased person, whether female or male." Id. at 196.

25. Id. at 179 .

26. Id. at 181 .

27. Id. 
positive feature is counterbalanced by a provision that allows men to divorce summarily while women must seek the intervention of the state: "[t]he Shari'a therefore restricts the wife's rights to divorce by making it contingent on a judge's ruling, whereas no such restriction is laid down in the case of the husband." 28

The reactions of other states to Algeria's reservation to CEDAW highlight that it seeks neither to balance the rights of women and men nor to promote the elimination of discrimination against women. ${ }^{29}$ Some European states consider that Algeria's reservation so places the dictates of international law at the mercy of its municipal law as to rid the treaty of its content. As such, Denmark, Portugal, and Sweden have notified the UN Secretary-General that they consider the reservation to be "incompatible with the object and purpose" of CEDAW. Following the decentralized regime of treaty reservations found in the Vienna Convention on the Law of Treaties, ${ }^{30}$ Algeria's reservation has been accepted by most parties to CEDAW by virtue of their acquiescence. ${ }^{31}$ Denmark, Portugal, and Sweden, on the other hand, have taken issue with its validity. As a result, these countries consider Algeria to be party to CEDAW, but they do not recognize Algeria's reservation. ${ }^{32}$

Quite apart from treaty reservations, Algeria and Egypt have further reduced their obligations through the imposition of states of emergency,

28. Id.

29. Consider the following statement by Mayer in relation to the issues of discrimination against women in the Islamic world, where she concludes that there is a "profound ambivalence that conservative Muslims feel about the principle of equality, a principle that they are in general reluctant to condemn openly but that they seek to circumvent by a variety of subterfuges." Ann Elizabeth Mayer, Islam and Human Rights: Tradition and Politics 96 (3d ed. 1999).

30. See Vienna Convention on the Law of Treaties, U.N. Doc. A/CONF.39/27 (1969), 1155 U.N.T.S. 331 art. 19-25 (entered into force 27 Jan. 1980) (articles 19-25), available at $<$ http://www.un.org/law/ilc/convents.htm> [hereinafter Vienna Convention].

31. See id. Article 20(5) of the Vienna Convention on the Law of Treaties reads:

$[\mathrm{U}]$ nless the treaty otherwise provides, a reservation is considered to have been accepted by a State if it shall have raised no objection to the reservation by the end of a period of twelve months after it was notified of the reservation or by the date on which it expressed its consent to be bound by the treaty, whichever is later.

Id.

32. See id. Article 21 sets out the legal effects of reservations and the effects of objections to such reservations. See id. Regarding the notifications of Denmark, Portugal, and Sweden, consider the following statement by the UN Secretary-General in his role as head of the UN treaty depository:

[s] everal Governments notified the Secretary-General that they consider the reservations made by the Government of Algeria upon accession as incompatible with the object and purpose of the said Convention and, therefore, prohibited by virtue of its article 28(2), on the dates indicated hereinafter: Sweden, 4 August 1997; Portugal 14 August 1997; and Denmark 24 March 1998.

Multilateral Treaties, supra note 10, at 195 n. 13. 
allowing them to suspend a number of rights in "time of public emergency which threatens the life of a nation." ${ }^{\prime 33}$ Article 4 of the ICCPR ${ }^{34}$ provides for such derogation but excludes fundamental rights such as, inter alia, those protecting life, freedom of thought, conscience, and religion, while prohibiting torture, slavery, and servitude. ${ }^{35}$ Thus, these states, in proclaiming public emergencies, may have effectively suspended the right to liberty and security of person, rights related to treatment in prison, mass expulsion of aliens, right to a fair trial, right to privacy, and freedoms of expression, assembly, and association, among others. ${ }^{36}$

\section{B. Southern African States}

Most states in Southern Africa share with North Africa the mark of a broad participation in the principle human rights conventions. The main exceptions are Botswana and Swaziland, which have the joint distinction of not being party to most of the important multilateral human rights treaties including, notably, Convention Against Torture and Other Cruel, Inhuman, or Degrading Treatment of Punishment (Torture Convention), ${ }^{37}$ ICCPR, $^{38}$ ICESR ${ }^{39}$ and the Genocide Convention. ${ }^{40}$ Swaziland is also not a party to CEDAW, ${ }^{41}$ although it is a party to the Racial Discrimination Convention. It is further noteworthy in the context of the region that neither state became a party to the International Convention on the Suppression and Punishment of the Crime of Apartheid (Apartheid Convention). ${ }^{42}$ South Africa is also still

33. Algeria decreed its state of emergency in 1992; Egypt did so in 1981. For the legality of the imposition of such long term states of emergency, see section IV(2) of this article regarding human rights situations in both these states.

34. ICCPR, supra note 13, art. 4.

35. See id. Article 4(2) of the ICCPR stipulates that there is to be "No derogation from articles 6, 7, 8 (paragraphs 1 and 2), 11, 15, 16 and 18 may be made under this provision." The right to life is found at article 6 ; freedom of thought, conscience, and religion at article 18; the provisions related to the prohibition of torture are found at article 7; slavery article 8(1) and servitude at article 8(2).

36. See id. arts. $9,10,13,14,17,19,21, \& 22$.

37. See id. at 201-02.

38. See id. at 129 .

39. See id. at 116-17.

40. See id. at 89-90.

41. See Multilateral Treaties, supra note 10 , at 179.

42. See International Convention on the Suppression and Punishment of the Crime of Apartheid, adopted 30 Nov. 1973, G.A. Res. 3068(XXVII), 1015 U.N.T.S. 243 (entered into force 13 July 1976), available at <http://www.unhchr.ch/html/menu3/b/11.htm> [hereinafter Apartheid Convention]. Information on signature, ratification, and reservations status is available in Multilateral Treaties, supra note 10, at 175. Current status information is also available at $<$ http://untreaty.un.org/ENGLISH/bible/englishinternetbible/ partl/chapterIV/treaty8.asp $>$. 
not a party to the Apartheid Convention, but this can be explained by the fact that the immediate threat of apartheid has now subsided, as well as by South Africa's amnesty process, which it might have difficulty reconciling with the terms of the Apartheid Convention. ${ }^{43}$ Lesotho has acceded to the Covenants and anti-discrimination treaties but unfortunately has not become a party to the Torture Convention. ${ }^{44}$

As is to be expected in a region with more states and less of a common sociopolitical background, there seems to be a little less coherence in the approach to international human rights treaties in Southern Africa as opposed to North Africa. Notwithstanding a general Southern African support for international human rights initiatives, only Namibia is a party to both ICCPR,${ }^{45}$ ICESR $^{46}$ the Racial Discrimination Convention, ${ }^{47}$ and CEDAW, ${ }^{48}$ as well as the Torture ${ }^{49}$ and Genocide Conventions. ${ }^{50}$ Angola is not party to the Racial Discrimination Convention, ${ }^{51}$ the Convention Against Torture, ${ }^{52}$ or the Genocide Convention. ${ }^{53}$ Mozambique has not ratified or acceded to ICESR, ${ }^{54}$ and South Africa has signed ICESR but has not yet followed up with its instrument of ratification. ${ }^{55}$ While Zimbabwe has not put its name to the Torture Convention, ${ }^{56}$ Zambia misses the Genocide Convention in its portfolio of treaty obligations. ${ }^{57}$ Malawi is also not a party to the Genocide Convention, ${ }^{58}$ but it is important to note that Malawi's constitution is one of the few in the world that makes specific reference to the prohibition on genocide. ${ }^{59}$

43. See Multilateral Treaties, supra note 10 , at 175. Article 1 of the Convention declares apartheid to be a crime against humanity and Article 3 imposes international responsibility. Apartheid Convention, supra note 43.

44. See Multilateral Treaties, supra note 10 , at 201.

45. See id. at 128-29.

46. See id. at 116-17.

47. See id. at 98-99.

48. See id. at 178-79.

49. See id. at 201-02.

50. See id. at 89-90.

51. See id. at 98-99.

52. See id. at 201-02.

53. See id. at 89-90.

54. See id. at 116 .

55. See id at 117 .

56. See id. at 201-02.

57. See id. at 90.

58. See id. at 89.

59. See Malawi. Const. art. 17, reprinted in 11 Constitutions of the Countries of the World (Gisbert H. Flanz ed., 1995).

Please note that for the sake of consistency, the first citation to a constitution will include information about the source wherein the document may be located. Subsequent references will include only the name and portion of the relevant constitution. 
What has been said earlier about the narrowing of treaty obligations through reservations and internal states of emergency does not generally apply to Southern African states. Swaziland appears to be the only state in a formal and constant state of emergency. ${ }^{60}$ There have been relatively few reservations with any discernable impact on the protection of human rights.

Only one Southern African state has compromised the compulsory procedures laid down for settling disputes over the interpretation of human rights treaties. Mozambique has done this in relation to the Racial Discrimination Convention. Its reservation reads:

The People's Republic of Mozambique does not consider to be bound by the provision of article 22 and wishes to restate that for the submission of any dispute to the International Court of Justice for decision in terms of the said article, the consent of all the parties to such a dispute is necessary in each individual case. ${ }^{61}$

This reservation does not entirely exclude the possibility of conferment of jurisdiction on the International Court of Justice (ICJ), but its reservation has the same effect as the North African examples by rejecting the notion of a "compromissary" clause to refer treaty disputes to the ICJ. Mozambique made a similar interpretative declaration to the Apartheid Convention. ${ }^{62}$

One of most intrusive forms of reservation to a human rights treaty purports to subjugate the treaty to domestic traditional law. Whereas the Shari'a has played a critical role in this respect in the northern region, one might have expected non-Islamic African states to have relied on African customary law as a necessary limitation to their ability to adopt essentially western conceptions of human rights. ${ }^{63}$ The only example of this kind of reservation from the foot of the African continent was Malawi's reservation to CEDAW which was subsequently withdrawn on 24 October $1991 .{ }^{64}$ This reservation read:

Owing to the deep rooted nature of some traditional customs and practices of Malawians, the government of the Republic of Malawi shall not, for the time

60. See Al, Amnesty International Report 1997 (Swaziland); Alan R. Booth, Swaziland: Tradition and Change in a Southern African Kingdom 74-79 (1983).

61. Multilateral Treaties, supra note 10 , at 103.

62. See id. at 176. Mozambique's declaration reads:

The People's Republic of Mozambique interprets article 12 of the Convention as to mean that the submission of any dispute concerning the interpretation and application of the Convention to the International Court of Justice shall be at the previous consent and request of the parties to the dispute.

Id.

63. See Josiah A.M. Cobbah, African Values and the Human Rights Debate: An African Perspective, 9 Hum. Rts. Q. 309 (1987) (provides an analysis of this debate).

64. See Multilateral Treaties, supra note 10 , at 196 n.30. 
being, consider itself bound by such of the provisions of the Convention as require immediate eradication of such traditional customs and practices. ${ }^{65}$

This format was a less radical approach than its Islamic counterparts. There was consequently no adamant objection that it would flout the object and purpose of the convention. Nevertheless, the Mexican government sent a communication to the Secretary-General expressing the hope, "that the process of eradication of traditional customs and practices referred to in the first reservation of the Republic of Malawi will not be so protracted as to impair fulfillment of the purpose and intent of the Convention."66

In ratifying CEDAW, while it does not place a general African customary or religious limitation on its obligations, Lesotho has effectively excluded two national institutions from their scope, i.e., holy orders and the monarch. ${ }^{67}$ Two other reservations, that of Zambia to the ICESCR ${ }^{68}$ and that of Swaziland to the Convention on the Rights of the Child, ${ }^{69}$ restrict the states obligation to implement the right to primary education. It is to be expected that African states would request some leeway with respect to social and economic rights, but these rights are in any event understood to be progressive in terms of the treaty obligations themselves.

These are isolated examples of reservations from Southern African states. A reservation by Botswana to the Convention on the Rights of the Child $^{70}$ and one by Lesotho to $\mathrm{CEDAW}^{71}$ are, in practice, of limited

65. Id.

66. Id. This communication was received by the Secretary General on 5 Aug. 1987. Id.

67. See id. at 183. Lesotho's reservation provides that:

The Government of the Kingdom of Lesotho declares that it does not consider itself bound by article 2 to the extent that it conflicts with Lesotho's constitutional stipulations relative to succession to the throne of the Kingdom of Lesotho and law relating to succession to chieftainship. The Lesotho government's ratification is subject to the understanding that none of its obligations under the Convention especially in article 2 (e), shall be treated as extending to the affairs of religious denominations.

ld.

68. See id. at 122 .

69. See Convention on the Rights of the Child, adopted 20 Nov. 1989, G.A. Res. 44/25, 1577 U.N.T.S. 3 (entered into force 2 Sept 1990), available at <http://www.unhchr.ch/ $\mathrm{html} / \mathrm{menu} 3 / \mathrm{b} / \mathrm{k} 2 \mathrm{crc} . \mathrm{htm}>$ [hereinafter Rights of Child Convention]. Information on signature, ratification, and reservations status is available in Multilateral Treaties, supra note 10, at 217. Current status information is also available at <http://untreaty.un.org/ ENGLISH/bible/englishinternetbible/partl/chapterIV/treaty15.asp>.

70. See Multilateral Treaties, supra note 10, at 220. Botswana's reservation to the Convention states:

The government of the Republic of Botswana enters a reservation with regard to the provisions of article 1 of the Convention and does not consider itself bound by the same in so far as such may conflict with the Laws and Statutes of Botswana.

Id.

71. See Multilateral Treaties, supra note 10, at 183. The second paragraph of Lesotho's reservation to CEDAW states: 
impact. $^{72}$ There are no instances of reservations by Angola, Malawi, Namibia, South Africa, and Zimbabwe to any of the major human rights instruments. ${ }^{73}$ There are also no meaningful reservations to the African Charter by Southern African states. Zambia's so called "reservations" are more in the nature of interpretative declarations. ${ }^{74}$ The states under review can therefore be said, barring a few exceptions, to have undertaken the full scope of the conventions they have ratified.

\section{CONSTITUTIONAL PROVISIONS}

\section{A. Constitutional Provisions in North Africa}

\section{General}

The constitutions of the North African states are, with the exception of Libya, a reflection of the legal systems inherited from their French colonial heritage. ${ }^{75}$ Algeria, Egypt, and Tunisia have integrated into their constitutional framework a "monist" relationship between international instruments and their respective municipal legal systems. As such, upon their ratification international instruments are to be considered part of the corpus juris without the need for the further promulgation of specific legislation. By contrast, the relationship between international and municipal law in Libya partly reflects its colonizer's "dualist" system, ${ }^{76}$ which

Furthermore, the Lesotho Government declares it shall not take any legislative measures under the Convention where those measures would be incompatible with the Constitution of Lesotho.

Id.

72. The former is meaningless because it subjects the application of the Convention to those under eighteen to the laws of the state. The treaty clause also does this in so far as the national law sets a younger age of majority. If the national law sets an older age of majority then the Child Convention will not apply to those over 18 in any event, so it means nothing to say that the state will not be bound by it in relation to those persons. The latter is meaningless in practice because the Lesotho Constitution fully protects against sex discrimination and so it is unlikely that legislation required to comply with the treaty would conflict with the constitution.

73. See, e.g., the two Covenants (ICESCR and ICCPR), supra notes 12 and 13 respectively, the two anti-discrimination conventions (Racial Discrimination Convention and CEDAW), supra notes 11 and 18 respectively, and the Torture and Genocide Conventions, supra notes 14 and 10 respectively.

74. See Human Rights Law, supra note 15, at 10.

75. See generally Duster: A Survey of the Constitutions of Arab and Muslim States (1966). See also François Terré, Introduction Générale au droit 79-81 (5th ed. 2000) (for the nature of the monist system as found in France).

76. Ian Brownlie explains that as part of the "dualist" theory, when "municipal law provides that international law applies in whole or in part within the jurisdiction, this is merely 
requires an act of the legislature before a treaty can be considered as part of the law of the land, while customary international law is generally considered as having direct application. ${ }^{77}$ While most states vest the legislative branch with the power to ratify international instruments, this is not the case in the North Africa.

The constitutions of the four states under consideration have vested the authority not only to conclude treaties but also to ratify them with their executive organ. Thus, the Algerian constitution, approved by a referendum on 28 November 1996, ${ }^{78}$ vests the powers of concluding and ratifying international treaties in the president of the Republic. ${ }^{79}$ The Revolutionary Command Council of Libya, the body which constitutes the "supreme authority in the Libyan Arab Republic" 80 and has the power to appoint "the President and Council of Ministers," 81 is likewise endowed with the authority to "conclude and ratify treaties and agreements." 82

In the cases of Tunisia and Egypt, while the ability to ratify international instruments is also within the purview of the executive, in both cases the presidents are limited in their authority by specific constitutional provisions.

The Tunisian constitution states clearly that the "President of the Republic ratifies the treaties," 83 and also makes plain that the status of such "[t] reaties duly ratified have an authority superior to [its municipal] law." 84 Yet, where an international instrument related to the "common interests" of

an exercise of the authority of municipal law, an adoption or transformation of the rules of international law." Ian Brownlie, Principles of Public International Law 33 (1995).

77. Libya was under the colonial rule of Italy from 1912-1943, after which Libya had mandate status under the League of Nations. The dualist system in Libya is explained in its report before the UN Human Rights Committee:

Every international instrument to which the Jamahiriya accedes and which is ratified by the basic people's congresses and published in the Official Gazette becomes binding and enforceable by the country's judiciary, in the same way as domestic legislation, with effect from the date of its publication in the Official Gazette.

Consideration of Reports Submitted by States Parties Under Article 40 of the Covenant: Third Periodic Reports of States Parties Due in 1995: addendum: Libyan Arab Jamahiriya, United Nations Human Rights Committee, II 31, CCPR/C/102/Add.1, 15 Oct. 1997 [hereinafter Libyan Report].

78. See Alg. Const., reprinted in 1 Constitutions of the Countries of the World (Gisbert H. Flanz ed., 1997) (see the introductory and comparative notes by Gisbert H. Flanz on pages $\mathrm{i}$ and $\mathrm{xi})$.

79. See id. art. 77, \$9.

80. Libya Const. art. 18, reprinted in 10 Constitutions of the Countries of the World (Albert P. Blaustein, Gisbert H. Flanz \& Thomas H. Ehrhardt eds., 1993).

81. Id. art. 19.

82. Id. art. 23.

83. Tunis. Const. art. 48, reprinted in 18 Constitutions of the Countries of the World (Albert P. Blaustein \& Gisbert H. Flanz eds., 1997).

84. Id. art. 32 . 
a "Great Arab Maghreb" would modify the Tunisian Constitution, the president has an obligation to submit the treaty to a referendum after it has been adopted by the national parliament. ${ }^{85}$

Likewise, the constitution of the Arabic Republic of Egypt provides that: "[t]he President of the Republic shall conclude treaties and communicate them to the People's Assembly, accompanied with suitable clarifications. They shall have the force of law after their conclusion, ratification and publication according to the established procedure." 86 This "established procedure" does not entail the approval of the Assembly, as long as treaties do not touch upon issues of territorial sovereignty, thus giving the president sole authority in all other areas. Article 151 of the Egyptian constitution goes on to limit the otherwise unimpeded prerogative of the president in the following matters:

[h] owever, peace treaties, alliance pacts, commercial and maritime and all the treaties involving modifications in the territory of the State, or having connection with the rights of sovereignty, or which lay upon the Treasury of the State certain charges not provided for in the budget, must acquire the approval of the People's Assembly. ${ }^{87}$

What inspires their unique manner of governance, and sets the Northern states apart from all other states on the continent, is their pledge to Islam as their official religion and Arabic as their official language. ${ }^{88}$ While the Algerian, Libyan, and Tunisian constitutions recognize their link to the African continent, this acknowledgment is secondary to their manifestations of Pan-Arabism. Thus, the Constitution of Algeria notes in its preamble that it is to be considered the "land of Islam, integral part of the Great Maghreb Arab country, Mediterranean and African." 89 Likewise the Libya Constitutional Proclamation makes a simple acknowledgment in Article 1 that its

85. See id. art. 2. The text of Article 2 provides:

The Tunisian Republic constitutes part of the Great Arab Maghreb, towards whose unity it works within the framework of common interests.

Treaties concluded to this effect and which shall be of such nature as to bring about any modification whatsoever in the present Constitution shall be submitted to a referendum by the President of the Republic after they have been adopted by the Chamber of Deputies in the forms and conditions foreseen by the Constitution.

86. Egypt Const. art. 151, reprinted in 6 Constitutions of the Countries of the World (Alfred P. Blaustein \& Gisbert H. Flanz ed., 1991).

87. Id.

88. For constitutional provisions related to Islam and Arabism as the bases of these states, see Alg. Const., art. 2 and 3; Egypt Const., art. 3; Libya Const., art. 2 and 1 respectively; Tunis. Const., art. 2 and 1 respectively.

89. Alg. Const., pmbl., II 10. 
"territory is a part of Africa,"90 while engaging its people through its preamble to fight for the "elimination of all obstacles which prevent Arab unity from the Gulf to the Ocean."91 Tunisia also pays homage to Africa in its preamble but proclaims that it is the will of its people "to remain faithful to the teaching of Islam, to the unity of the Greater Maghreb, to its membership of the Arab family." ${ }^{92}$ It merely pledges "cooperation with the African peoples in building a better future." ${ }^{\prime 93}$ Egypt for its part fails to mention Africa in its constitution, but indicates that one of its fundamental aspirations is to be a union of the Arab nation, stating:

the hope of our Arab nation, being convinced that Arab unity is a call of history and of the future, and a demand of destiny; and that it cannot materialise except through an Arab nation, capable of warding off any threat, whatever the source or the pretexts for such a threat. ${ }^{94}$

Beyond the Pan-Arabist theme pervading these documents, anticolonial and socialist underpinnings emerge. Only the Tunisian constitution excludes socialist rhetoric. However, its anticolonial bent is evident from its constitutional aspirations, expressed against the backdrop of its people having been "set free from foreign domination thanks to its powerful cohesion and to its struggle against tyranny, exploitation and regression. . . ."95 The constitutions of Algeria, Egypt, and Libya certainly mirror these anticolonial overtures, but bear more prominent socialist aspirations as their underlying philosophy. In this vein, the Algerian constitution mandates that "The people establish institutions which have as their objectives: . . . the suppression of the exploitation of man by man" ${ }^{\prime 96}$ and that these institutions "forbid the establishment of relations of exploitation and bonds of dependency." 97 The Socialist People's Libyan Arab Jamahiriya

90. LiBYA CONST., art. 1. Article 1 further provides, inter alia, that "[t]heir [the Libyan People's] goal is total Arab Unity."

In addition, the Libyan government has spoken to the issues of Arab unity in a report to the UN Human Rights Committee where it stated that:

The territory of the Libyan Arab Jamahiriya forms part of the Arab world and its people form part of the Arab nation. Its language is Arabic, its religion is Islam and its people, who are of Arab origin, constitute a united and homogenous population group which was formed in Libyan territory, as in the case of the other North African countries, through ancient and subsequent Arab migrations. ...

Libyan Report, supra note 77, II 9.

91. 91. Id. pmbl., II 2.

92. Tunis. CONST., pmbl., II 2.

93. Id.

94. Egrpt. COnst., const. procl., II 7.

95. Tunis. Const., pmbl., II 2.

96. Alg. Const., art. 8.

97. Id. art. 9. 
(Republic), as this official title indicates, embraces a socialist framework within its constitution. Acknowledging its underdevelopment as a product of its colonial past, ${ }^{98}$ the constitution notes that the aim of the Libyan state:

is the realization of socialism through the application of social justice which forbids any form of exploitation. The state endeavors, through the edification of a socialist community, to achieve self-sufficiency in production and equity in distribution. Its aim is to eliminate peacefully the disparities between social classes and to attain a society of prosperity. ${ }^{99}$

The Egyptian constitution goes further, plainly stating in Article 1 that it "is a democratic, socialist state based on the alliance of the working forces of the people"100 and under Article 7 that "[s]ocial solidarity is the basis of the society."

\section{Provisions Relating to Human Rights}

Taking as a backdrop the elements of Islamic faith, Pan-Arabism, colonial independence, and socialist affiliation, it is now time to turn to the specific human rights and duties which these states have integrated into their constitutional frameworks. Before turning to human rights, it should be noted that all four states, in line with the African Charter, integrate duties into their constitutions ${ }^{102}$ with a commonality being the duty to defend the state. ${ }^{103}$ The Algerian constitution is the only constitution under review that grants a number of human rights without limitation. Thus Article 29, providing for equal treatment before the law without discrimination, Article 34 , providing for inviolability of the human person, Article 36, providing for

98. See the Preamble to the Libyan Constitution which reads in part that its people are people "who are determined to break the shackles which impede their growth and their development, who will stand with their brothers from all parts of the Arab nation in the struggle for the restoration of every inch of Arab land desecrated by imperialism . . ." LiBYA CONST., pmbl., II 2. The preamble goes on to state that its people are people "who understand fully that the alliance of reaction and imperialism is responsible for their underdevelopment despite the abundance of their natural resources, and for the corruption which spread through the governmental apparatus." LiвYA CONST. II 4.

99. Id. art. 6.

100. EGYPt. Const., art. 1.

101. Id. art. 7.

102. For provisions related to duties in the various constitutions see: Alg. Const., ch. 5 (entitled "Duties"), arts. 60-69; Egypt Const., arts. 58-62; LibyA Const., art. 16; and Tunis. CONST., arts. 15 and 16.

103. The nomenclature of these provisions is colorful enough to quote, which indicate that the defense of "his fatherland" (Alg. Const., art. 62); "the motherland" (Egrpt Const., art. 58); "the homeland" (LiBYA Const., art. 16); or "the country" (Tunis. Const., art. 15) is a sacred duty. 
freedom of conscience and opinion, and Article 54, providing for health protection, are inviolable as they are not constitutionally subject to limitations. ${ }^{104}$ By way of contrast, Tunisian citizens:

exercise the plentitude of their rights in the forms and conditions foreseen by the law. The exercise of these rights cannot be limited except by a law enacted for the protection of others, the respect for the public order, the national defense, the development of the economy and social progress. ${ }^{105}$

The Tunisian constitution enumerates a number of rights allotted to its citizens, including the freedoms of opinion, expression, the press, assembly, and association which are all guaranteed within "the conditions defined by the law." 106 The Tunisian Constitution also provides for the inviolability of the domicile "save in exceptional cases foreseen by the law,"107 and freedom of movement, with the proviso that such a right is "within the limits foreseen by the law." 108 Egypt also limits the rights it has prescribed in its constitution to the dictates of its municipal legislation. While freedom of opinion is guaranteed by Article 47, such freedom is to take place "within the limits of the law."109 Freedom of movement is likewise provided for "except in the cases defined by the law."110 The Libyan constitution gives little expression to human rights provisions, prescribing only two. It allows for the inviolability of the home under Article 12, but allows for exceptions "under the circumstances and conditions defined by law"; it also allows for freedom of expression under Article 13, so long as they are "within the limits of public interest and the principles of the Revolution." 111

104. See Alg. Const., arts. 29, 34, 36, and 54. Though Algeria's constitution is the only granting many human rights without limitation, it should be noted that the Egyptian Constitution does provide one human rights provision without qualification, Article 40, which provides equality before the law. See Eqrpt Const., art. 40.

105. Tunis. Const., art. 7.

106. Id. art. 8.

107. Id. art. 9.

108. Id. art. 10 .

109. Id. art. 47.

110. EGrpt. COnst., art. 50.

111. LibYa Const., arts. 12, 13. Note that education is both a right and a duty in Libya. See id. art. 14 . 


\section{B. Constitutional Provisions in Southern Africa}

\section{General}

Similar to the North African scenario, the treatment of international law by the domestic authorities in Southern Africa is linked to the colonial histories of the respective states. Accordingly, those states deriving influence from the British, including Botswana, Lesotho, Malawi, South Africa, Swaziland, Zambia, and Zimbabwe, are essentially "dualist." Meanwhile, Namibia's German heritage and Angola's and Mozambique's Portuguese past have left them with monist systems in relation to the rapport between treaties and their own legal systems. South Africa's new constitution borrows elements from both the monist and dualist traditions. While persisting with the requirement of incorporation through the legislature, it has adopted the concept of "self-executing" provisions of a treaty. ${ }^{112}$ Such provisions, once approved by parliament for the purposes of ratification, can be applied without an act of parliament. The conception is that of a self-executing "provision," as opposed to a self-executing treaty, but it is, as yet, unclear how this provision will be interpreted. ${ }^{113}$

A legacy of colonial rule in Southern Africa is the partial or total adoption of democratic institutions and principles developed through historical struggles in the home territories of the colonial rulers. ${ }^{114}$ Botswana, Lesotho, Malawi, and Zambia's constitutions all inherit the basic pillars of British democracy including free elections and freedoms of expression, association, and assembly. ${ }^{115}$ Both South Africa's and Zimbabwe's fully democratic statuses ${ }^{116}$ emerged from the dynamics associated with their

112. See S. Afr. Const. ch. 14, § 231(4), reprinted in 16 Constitutions of the Country of the Wortd (Gisbert H. Flanz ed., 1996).

113. The distinction between a self-executing and non self-executing treaty has long caused difficulties for the courts of the United States. See, e.g., Foster v. Neilson, 27 U.S. (2 Pet.) 253 (1829); United States v. Percheman, 32 U.S. (7 Pet.) 51 (1833); Edye v. Robertson, 112 U.S. 580 (1884); United States v. Postal, 589 F.2d 862 (1979), and cert. denied, 444 U.S 832 (1979); Linder v. Portocarrero, 747 F.Supp 1452; see also Yuji Iwasawa, The Doctrine of Self-Executing Treaties in the United States: A Critical Analysis, 26 VA. J. INT'L L. 627,635 (1986); Carlos M. Vasquez, The Four Doctrines of Self-Executing Treaties, 89 AM. J. INT'L L. 695 (1995).

114. In England the development of the rights of citizens not to be oppressed by the state really began with the Magna Carta in 1215 .

115. See Bots. Const. ch. $1, \S \S 12,13$, and 11 respectively, reprinted in 3 CONSTITUTIONS OF THE Country of the World (Alfred P. Blaustein \& Gisbert H. Flanz eds., 1989); Lesotho Const. $\S \S 1(1), 14,15,16$ respectively, reprinted in 10 Constitutions of THE Country OF THE WorLD (Gisbert H. Flanz ed., 1999); MalaWI Const., §§ 1(6), 35, 32, and 38 respectively; and Zambia Const. $\S \S 1(2), 20,21$, and 11 respectively, reprinted in 20 Constitutions of the Country of the World (Gisbert H. Flanz ed., 1998).

116. See S. Afr. Const. ch. $1, \S 1 ;$ Zimb. Const. $\S 1$. 
respective struggles against discriminatory regimes. Until recently, Mozambique had been ruled as a one party state, but civil war culminated in transition to democracy and the first multiparty elections pursuant to its 1990 constitution were held in 1994. ${ }^{117}$ Angola's postindependence constitution recognized only one party; however, in December 1990, the People's Movement for the Liberation of Angola (MPLA) announced that the constitution would be revised to allow opposition parties. ${ }^{118}$ Accordingly, Article 4 of Angola's current constitution provides that political parties shall compete.

The current status of Southern African constitutions is that all, with the exception of Swaziland, provide for multiparty democracy. Swaziland's postindependence constitution of 1968 also contained a bill of rights and provisions protecting democratic rights. However, this constitution was suspended in 1973. A new constitution was promulgated in 1978 but was not presented to the people. ${ }^{119}$ Swaziland therefore currently has no written constitution; a 1973 decree banned all political organizations and activities. ${ }^{120}$ A Constitutional Review Commission was established in July 1996, ${ }^{121}$ but the lack of visible progress and withdrawal of interested parties from the process has led to doubts over its credibility and the likelihood for Swaziland gaining a constitution in the near future. ${ }^{122}$

\section{Provisions Relating to Human Rights}

As opposed to North African states which have limited provisions relating to human rights incorporated into their constitutions, many states in Southern Africa, including Botswana, Lesotho, South Africa, Swaziland, Zambia, and Zimbabwe, incorporated a bill of rights into their constitutions when majority rule was established. ${ }^{123}$ While Botswana and Zimbabwe retained their respective postindependence constitutions of 1966 and 1979, ${ }^{124}$ other

117. See Larry Benjamin \& Christopher Gregory, Southern Africa at the Crossroads? Prospects for Stability and Development in the 1990s 81 (1992).

118. See Mozambique 1962-1993: A Political Chronology 167-201 (David Hoile ed., 1994).

119. See Eduardo Serpa, The Mozambican Elections, Al Bulletin, 1994.

120. See 240 The Annual Register: A Record of World Events 308 (Alan J. Day ed., 1998).

121. See 239 The Annual Register: A Record of World Events 288 (Alan J. Day ed., 1997).

122. See id.

123. See, e.g., Lesotho Const., The Lesotho Indep. Order 1966 (Statutory Instrument No. 1966, No. 1172), Supplement to Gazette No. 4. See Bots. Const., The Bots. Indep. Order 1966 (Statutory Instrument 1966, No. 1171). It should be noted that the Human Rights Act 1998 merely requires a judge to have regard to the European Convention on Human Rights, but does not incorporate its provisions into English law.

124. See Bots. Const. Botswana Chronology, i, iii. The Bostwana as amended in 1966 is contained in Schedule 2 to The Bots. Indep. Order 1966). Id. Zıмв. Const. reprinted in 20 Constitutions of the Countries of the World (Gisbert H. Flanz ed., 1998). The former Rhodesia was never recognized as a newly independent state. 
states have promulgated new constitutions but have continued to insure that a bill of rights is an integral part of their constitutions. ${ }^{125}$ The constitutional reforms of Angola and Mozambique also incorporated the adoption of fundamental rights.

The African Charter provides in Article 13 for the right to participate freely in government directly or through freely chosen representatives. ${ }^{126}$ Most Southern African constitutions expressly recognize the right to vote and to participate in government. ${ }^{127}$ While the constitutions of Botswana and Zimbabwe do not expressly achieve this end, these rights are part of the unwritten constitutional framework inherited from the British. ${ }^{128}$ Moreover, all of the Southern African constitutions protect freedom of expression, ${ }^{129}$ while five of them expressly recognize press freedom. ${ }^{130}$ Indeed, Southern African constitutions can be said to go beyond the African Charter in their protection of democracy in that they all expressly or implicitly protect the right to form political parties. ${ }^{131}$ By contrast, the African Charter was concluded in the context of certain states vigorously defending the notion of the "one party" or "non partisan" so-called "democracies."132

The traditional civil rights, including the right to life, the right not to be subjected to cruel inhuman or degrading treatment, the right to liberty and security of person, the right to property, and the right to equality, are

125. Lesotho's constitution was adopted in 1993, although it retains much of the postindependence language. See Inter-University Associates, Inc., Lesotho: 1993-1999, in Lesotho Const. Malawi's constitution was adopted in 1994. See Gisbert H. Flanz, Malawi: Introduction: 1993/94, ix, in 11 ConstiTutions OF THE World (Gisbert H. Flanz ed., 1995). Namibia's constitution was adopted in 1990. See Namibia Chronology, iii, ix, in 12 Constitutions of the Country of the World (Gisbert H. Flanz ed., 1995); South Africa's "final" constitution was adopted in 1996 and the interim in 1993. See Medard Rwel Amira, South Africa: Introductory and Comparative Notes, vii, in 16 Constitutions OF THE WORLD (Gisbert H. Flanz ed., 1996). Zambia's constitution was adopted in 1991. See generally Zambia Const.

126. See African Charter, supra note 4, art 13.

127. AnGl. Const. arts. 3(2), 28(1), adopted 25 Aug. 1992, available at <http://www.uniwuerzburg.de/law/ao00000_.html>; Lesotho CONST. § 20(a) \& (b); MAlAwI ConST. § 40(1)(a)(d),(3); Mozam. Const. art. 30 , reproduced in 12 Constitutions of the Countries of the World (Alfred P. Blaustein \& Gisbert H. Flanz eds., 1992); NamiB. Const. arts. 17(2),(3); S. Afr. Const. §§ 19(2),(3); Zambia Const. § 1(2).

128. See generally E.C.S. Wade \& A.W. Bradley, Constitutional and Administrative Law (10th ed. 1985).

129. See Angl. Const. art. 32(1); Bots. Const. § 12; Lesotho Const. § 14; Malawi Const. § 35; Mozam. Const. art. 74(1); Namib. Const. art. 21 (1)(a); S. Afr. Const. § 16; Zambia Const. art. 20; Zimb. Const. § 20.

130. See Angl. Const. art. 35; Namibia Const. art. 21 (1)(a); Mozam. Const. arts. 74(1),(3); S. Afr. CONST. art. 16 (1)(a).

131. See Angl. Const. art. 4; Bots. Const. $§ 13$ (freedom of association); Lesotho Const. § 16(1) (freedom of association for political purposes); MalawI Const. § 40(1); Mozambique art. 30; S. Afr. Const. § 19(1)(a); Zambia Const. art. 21(1); Zimb. Const. § 21.

132. Tanzania, Uganda, and Zambia are examples. 
protected in all of the constitutions of Southern states. To these one can add the right to have one's cause heard, ${ }^{133}$ the right to freedom of movement, ${ }^{134}$ and the rights to freedom of conscience and religion. ${ }^{135}$ The right to be free from slavery and forced labor is expressly protected in all of the constitutions except those of Angola and Mozambique. ${ }^{136}$ While the prohibition against inhuman treatment is covered by all of these constitutions, ${ }^{137}$ the right to human dignity, as a broader notion, is protected in all but three. ${ }^{138}$ With respect to equality provisions, race, color, and sex are stated as grounds for unlawful discrimination in every constitution, and there is a reference either to religion or to creed as another basis for protection. ${ }^{139}$ Other grounds often referred to include place of birth, ethnic origin, and political opinion. Lesotho's, Namibia's, and South Africa's equality provisions are not exhaustive as to the possible grounds for discrimination, leaving the possibility for "other status" to be determined by their courts.

There is least coherence on the issue of the death penalty. The constitutions of Angola, Mozambique, and Namibia expressly prohibit its use. ${ }^{140}$ In contrast, the constitutions of Botswana, Lesotho, Malawi, Zambia, and Zimbabwe expressly permit its use. ${ }^{141}$ The South African constitution is silent on the matter, but in its first case, the Constitutional Court interpreted the constitution as prohibiting the use of the death penalty. ${ }^{142}$

133. See Angl. Const. art. 43; Bots. Const. § 18; Lesotho Const. § 22; Malami Const. § 41; Mozam. Const. arts. 80(1), 82; Namibia Const. art. 25(2); S. Afr. Const. § 34; Zambia Const. art. 28; Zімв. CоNST. § 24.

134. See Angl. Const. art. 25; Bots. Const. § 14; Lesotho Const. § 7; Malawi Const. § 39; Mozam. Const. art. 83; Namib. Const. art. 21(1)(g)-(i); S. Afr. Const. § 21; Zambia Const. art. 22; Zıмв. Const. § 22.

135. See Angl. Const. art. 45; Bots. Const. § 11; Lesotho Const. § 13; Malawi Const. § 33; Mozam. Const. art. 78 (religion only); Namib. arts. 21(1)(b),(c); S. Afr. Const. § 15; Zambia Const. art. $19 ;$ Zimb. Const. § 19.

136. See Bots. Const. § 6; Lesotho Const. § 9(1); Malawi Const. § 27(1),(2); Namib. Const. §9; S. Afr. Const. § 13; Zambia Const. art. 14(1); Zimb. Const. § 14(1).

137. See Angl. Const. art. 23, Bots. Const. § 7; Lesotho Const. § 8; Malawi Const. § 19(3); Mozam. Const. art. 70; Namib. Const. art. 8(2)(b), S. Afr. Const. $\$ 10$ (right to human dignity); Zambia Const. art. 15; ZIMB. Const. $\$ 15$.

138. See Angl. Const. art. 20; Malawi Const. § 19(1),(2); Mozam. Const. § 70; Namib. Const. art. 8; S. Afr. Const. § 10; Zambia Const. Botswana, Lesotho, and Zimbabwe are the exceptions.

139. See Angl. Const. 18; Bots. Const. § 15(3); Lesotho Const. § 19; Malawi Const. § 20(1); Mozam. Const. art. 66; Namib. Const. § 10(2); S. Afr. Const. § 9(3); Zambia Const. art. 23(3); Zimb. Const. § 23 (1),(2).

140. See Angl.Const. art. 22(2); Mozam. Const. art. 70(2); Namib. Const. art. 6.

141. See Bots. Const. § 4; Lesotho Const. § 5(2); Malawi Const. § 16; Zimb. Const. § 12(1).

142. See The State v Makwanyane + M Mchunu, III 144-151, Case No. CCT/3/94, Const. Ct. of the Repub. of S. Afr. (1995)(3)SA 391 (CC). The court considered the constitutionality of the use of the death penalty from several perspectives including the right to life, the right to dignity, the right to humane treatment, and the right to equality. It referred to an impressive array of foreign and international jurisprudence before unanimously ruling against the constitutionality of the death penalty. See id. 
The rights of refugees and the right to family life, protected under the African Charter, ${ }^{143}$ are poorly protected in the constitutions. The former finds expression only in the constitution of Angola. ${ }^{144}$ The latter is only expressly dealt with in the constitutions of Angola, Malawi, and Namibia. ${ }^{145}$ The African Charter also protects social rights, in particular the right to work under equitable and satisfactory conditions ${ }^{146}$ and the right to education. ${ }^{147}$ Only Botswana and Zimbabwe fail to protect these rights in their constitutions. These omissions, as well as those just mentioned in the context of civil rights, are partly explicable by the age of the constitutions. The inclusion of social and economic rights, family rights, and refugee rights in national constitutions are more recent phenomena that had not found expression in the postindependence bills of rights left by the British. Nonetheless, most Southern African constitutions are of recent origin and have, it seems, simply failed to address asylum in line with the African Charter.

The African Charter's emphasis on duties is also notably absent from the majority of Southern constitutions. Duties that are imposed on individuals by treaties have little meaning unless reflected in the domestic provisions of the state. Only the constitutions of Mozambique and Angola reflect this trend. In Mozambique, citizens have a duty similar to that in North African states to defend the state. This duty is expressed in the following terms: "[i]t shall be a sacred duty and honour for all Mozambican citizens to participate in the defence of the country's independence, sovereignty and territorial integrity. ${ }^{\prime 148}$ They also have the duty to respect the constitutional order. ${ }^{149}$ In Angola, citizens have the duty "to take an active part in public life, to vote, to stand for election. . . to fulfil their offices with full dedication to the cause of the Angolan nation," ${ }^{150}$ and to work. ${ }^{151}$ Families have the duty, with cooperation from the state, "to promote and ensure the all-round education of children and young people."152

All of the constitutions under review allow for the limitation of rights either through general limitation clauses or "claw back" subclauses. Only the constitution of Malawi expressly states certain rights not subject to

143. See African Charter, supra note 4, art. 18.

144. See Angl. Const. art. 26.

145. See Angl. Const. art. 29; Malawi Const. § 22; Namib. Const. art. 14.

146. See African Charter, supra note 4, art. 15.

147. See id. art. 17.

148. Mozam. Const. art. 84(1).

149. See id. art. 85(1).

150. Angl. Const. art. 28(1).

151. See id. art. 46(1).

152. Id. art. 29(3). 
limitation. ${ }^{153}$ Contextually, it is clear that slavery and servitude are not subject to limitation in the constitutions of Lesotho, Malawi, Namibia, Zambia, and Zimbabwe because they are covered neither by a general limitation clause nor by a "claw back"154 clause. ${ }^{155}$ This can also be said for the right to human dignity, torture and inhuman treatment, the right to life, and the right to equality in the constitution of Namibia. ${ }^{156}$

General limitation clauses come in two forms. One, which is common to all these constitutions, is that which allows for derogation in time of war or state of emergency. ${ }^{157}$ The other is a more general type found in the constitutions of Angola, Malawi, Mozambique, Namibia, and South Africa. ${ }^{158}$ South Africa's limitation clause, for instance, provides that:

(1) [t]he rights in the Bill of Rights may be limited only in terms of law of general application to the extent that the limitation is reasonable and justifiable in an open and democratic society based on human dignity, equality and freedom, taking into account all relevant factors, including-

(a) the nature of the right;

(b) the importance of the purpose of the limitation;

153. These include:

(a) the right to life;

(b) the prohibition on torture and cruel, inhuman or degrading treatment or punishment;

(c) the prohibition on genocide;

(d) the prohibition of slavery, the slave trade and slave like practices;

(e) the prohibition of imprisonment for failure to meet contractual obligations;

(f) the prohibition on retrospective criminalization and retrospect imposition of greater penalties for criminal acts;

(g) the right to equality and recognition before the law;

(h) the right to freedom of conscience, belief, thought and religion and academic freedom; or

(i) the right to habeas corpus.

MaLAWI Const. § 44.

154. The term "claw back' clause" refers to phrases included in protective provisions that serve to limit the rights prescribed in those provisions. For information on such clauses in the African Charter, see Thomas Buergental, International Human Rights 232-34 (2d. ed. 1995). Buergental further cites to Flinterman \& Ankuman, The African Charter on Human and Peoples' Rights, in Guide to International Human Rights Practice 165-66 (H. Hannum ed., 2d ed., 1992).

155. See Lesotho Const. § 9(1),(2); Malawi Const. § 27(1)-(4); Namib. Const. art. 9(1),(2); Zambia Const. art. 14(1),(2); ZIMB. Const. § 14(1).

156. See Namib. Const. arts. 8(1),8(2)(a); 8(2)(b); 6; 10(1),(2), respectively.

157. See Angl. Const. art. 52 ; Bots. Const. § 16(1); Lesotho Const. § 21(1); Malawi Const. $\S 45(1)$; Mozam. Const. art. 106(1); Namib. Const. art. 24(1); S. Afr. Const. § 37(4); Zambia Const. art. 25; Zıмв. Const. § 25.

158. See Angl. Const. art. 52(1); Malawi Const. § 44(2); Mozam. Const. art. 96(2); Namib. Const. arts. 22, 21(2); S. Afr. Const. § 36. 
(c) the nature and extent of the limitation;

(d) the relation between the limitation and its purpose; and

(e) less restrictive means to achieve the purpose. ${ }^{159}$

The concept that limitations being reasonable in an open and democratic society is also common to the constitutions of Malawi and Namibia. ${ }^{160}$ These types of provisions define the scope of permissible limitations rather than leaving that job to the legislature as is done with some of the quoted examples from North Africa. The claw back clauses in the Southern constitutions generally also define the permissible scope of limitation. For instance, Section 13(5)(a) of the Lesotho Constitution allows the freedom of conscience to be limited "in the interests of defence, public safety, public order, public morality and public health."161

\section{THE HUMAN RIGHTS SITUATION}

\section{A. Transgressions of Human Rights in Northern Africa}

\section{General}

The four Northern states under review have systematically abused human rights as a means of suppressing "Islamic"162 groups that challenge their authority. The basic dynamic that leads to such abuses in each of these states is a ruling elite, often times Western in orientation and secular in nature, which attempts to maintain control over a constitutionally enshrined

159. S. Afr. Const. $§ 36$.

160. See Malawi Const. § 44(2); Namib. Const. art. 21(2).

161. LESOTHO CONST. § 15(a).

162. We have placed "Islam" between quotation marks to indicate the Western proclivity to give it a monolithic character without acknowledging the many variations within the Muslim tradition. Regarding this point, Edward W. Said writes:

One of the points I make here and in [my previous book] Orientalism is that the term "Islam" as it is used today seems to mean one simple thing but in fact is part fiction, part ideological label, part minimal designation of a religion called Islam. In no really significant way is there a direct correspondence between the "Islam" in common Western usage and the enormously varied life that goes on within the world of Islam, with its more than $800,000,000$ people, its millions of square miles of territory principally in Africa and Asia, its dozens of societies, states histories, geographies, cultures.

Edward W. Said, Covering Islam: How the Media and the Experts Determine How we see the Rest OF THE WORLD 1 (1997).

It should come as little surprise then, that the Western-oriented governing regimes in the northern African states have picked up on this rhetorical tool to justify suppressing popular movements. 
"Islamic" state. Measures of repression meant to stay the tide of the various Islamic movements are manifest in the limitations to and violations of freedom of expression, freedom from arbitrary arrest, and manifest unfair trials. Further, systematic arbitrary arrest, detention, and torture remain means of instilling fear into opposition groups that today find representation, more often than not, under the aegis of Islam.

The so-called "Islamic movements" that have emerged have more to do with democratic aspirations, i.e. the ability to "have a say" in one's public life, than religious dogma. Having suppressed democracy through the limitation of true political participation, ${ }^{163}$ the majority of citizens have turned to religious groups as a means of expressing their disenchantment with illegitimate regimes. ${ }^{164}$ Further, some of these Islamic groups, such as the Muslim Brotherhood in Egypt and the Front Islamique de Salut (FIS) in Algeria, have often proven themselves "better organized, more efficient and less corrupt than the government administration[s]" in providing services to their fellow citizens. ${ }^{165}$ These governments, threatened by the challenge to their legitimacy and weakening of their power base, have subjugated the rights that they have readily embraced in written form to repressive

163. For example, Lisa Anderson writes that in none of the instances of the so called liberalization of the political process in North Africa or the Middle East "did regimes intend to actually confront competitors for power. In both intent and content, these reforms were designed not to inaugurate a system of uncertain outcomes-democracy — but to solidify and broaden the base of the elite in power ...." Lisa Anderson, Fulfilling Prophecies: State Policy and Islamist Radicalism, in Political Islam: Revolution, Radicalism, or Reform? 17, 20 (John L. Esposito ed., 1997).

In his introduction, editor John L. Esposito gives an overview of Anderson's piece, stating:

Drawing on the Tunisian, Algerian, and Moroccan experiences, she demonstrates the extent to which [Islamic] movements have been "reactionary," i.e., developed their policies in reaction to regime policies. Thus, she notes that the failure to provide detailed programs and the tendency to resort to violence are often in reaction to government policies.

John L. Esposito, Introduction, in Political Islam: Revolution, Radicalism, or Reform? 1, 5 (John L. Esposito ed., 1997).

164. For instance, Paul J. Magnarella writes:

Regimes that fail to respect human rights never gain genuine legitimacy, because large segments of the peoples they rule and abuse simply refuse to recognize them as legitimate. Such regimes too frequently resort to military/police force to maintain power by suppressing political opponents and disgruntled civilians. They violate economic, civil, and political rights on the false pretext of "national security." Alas, this has too often been the experience in the Middle East and North Africa.

Paul J. Magnarella Introduction, in Middle East and North Africa: Governance, Democratization, Human Rights 1, 2 (Paul J. Magnarella ed., 1999).

165. Anderson, supra note 163 , at 24. Such services include "providing free medicine, distributing school equipment, organizing garbage collection, offering ... administrative advice," and also "provid[ing] emergency relief services ... guarantee[ing] law and order ... [and] providing policing. ..." Id. 
measures meant to consolidate and maintain their unrepresentative governments in the wake of popular Islamic challenges.

\section{State Specific Situations}

\section{a. Algeria}

During the past decade, there has been a quagmire of human rights abuses in Algeria as a direct result of the military suppression of the FIS, which was victorious in the elections of 1991 and was poised to win the canceled second round of parliamentary elections scheduled for early $1992 .^{166}$ In attempting to ensure that the FIS would not reap its democratic spoils, a de facto coup took place whereby the army usurped control of the state and imposed a state of emergency giving itself wide discretion in its move to suppress this popular and democratic movement. As Mohammad-Mahmoud Mohamedou, Director of Research at the International Council on Human Rights Policy, noted: "The Algerian government's refusal to abide by the 1991 election results, followed by a silent coup d'État and an anti-Islamist campaign including emergency military trials, torture, and assassinations, led to a civil war between the Algerian army and the three main Islamist groups. . . ."167

As a result of widespread oppression by government forces, the Islamic opposition took up arms. ${ }^{168}$ While the Western media was quick to place the blame of the fratricidal conflict on "Islamic terrorism," Amnesty International reported that: "Responsibility for human rights abuses could often not be established because security forces, militias armed by the state and armed groups defining themselves as Islamic groups often adopted similar patterns of conduct and because there were no investigations."169

This final point is worth highlighting as the Algerian authorities, while placing the blame on Islamic terrorists, have "refused to allow access to UN human rights experts and to international human rights organizations." 170

166. See luis Martinez, The Algerian Civil War 1990-1998 (2000) (see Part I "The Shaping of the Civil War").

167. Mohammad-Mahmoud Mohamedou, The Rise and Fall of Democratization in the Maghreb, in Middle East and North Africa: Governance, Democratization, Human Rights, supra note 164 at 209, 215.

168. Lisa Anderson, citing a 1994 Human Rights Watch report, notes that "[t]hus did FIS militants who rejected violence during the all too brief democratic experiment in Algeria respond in kind to government violence after the military coup." Anderson, supra note 163 , at 29.

169. Amnesty International (AI), Amnesty International Report 1999 (Algeria) 73.

170. Algeria; UN Panel report a Whitewash on Human Rights, Amnesty International, AfricA News Service, 16 Sept. 1998, MDE 28/32/98, <available at http://web.lexis-nexis.com/ universe>. 
The relevance of this refusal may coincide with the increased "suspicion among Algerians that many of the terrorist acts, up to and including assassinations of police officers, may be the work of élite units of the [government's] security forces themselves or their agents provocateurs among the Islamists." 171

In its 1999 report on Algeria to the UN Commission on Human Rights, Amnesty International noted that human rights abuses "continue on a large scale." 172 These abuses continued despite the promulgation of a new constitution in $1996{ }^{173}$ and the "unilateral truce declared in October 1997" by the military wing of the FIS, which precipitated a formal end to the civil war. ${ }^{174}$ Amnesty International reports, however, seem to indicate that the war is not over, as the "level of violence remained high throughout the year, but appeared to be lower than in 1997."175 Security forces and militias armed by the state continued to be responsible for extrajudicial executions, deliberate and arbitrary killings, torture, "disappearances" and arbitrary detention. ${ }^{176}$

\section{b. Egypt}

Algeria may be moving towards state repression based upon an Egyptian model, which includes an undeclared war against popular uprisings by labeling the enemy "Islamist." As Mamoun Fandy and Dana Hearn from the Center of Contemporary Arab Studies at Georgetown University have noted:

Faced with a crisis of popular legitimacy, the government seeks to silence voices which undermine its tenuous hold on ideological credit. Islamist groups, considered the state's most threatening challengers, bear the brunt of these efforts. Drawing on emergency laws and anti-terrorism amendments, the state has increasingly resorted to coercive tactics and flagrantly undermined the rights to life, personal safety, and freedom. ${ }^{177}$

171. Mohamedou, supra note 167 , at 219.

172. Al, 1999 U.N. Commission on Human Rights: Making Human Rights Work: Time to Strengthen the Special Procedures, Appeal case: Algeria, 1, Al Index: MDE 28/03/00 (1999).

173. Note that an important addition to the constitutional framework of Algeria is the outlawing of religious based political parties. Article 42 reads, in part, "[i]n respect to the provisions of the present Constitution, the political parties cannot be founded on a religious, linguistic, racial, sexual, corporatist, or regional basis." ALg. Const., art. 42.

174. Al Report (Algeria), supra note 169, at 73.

175. Id.

176. See id. at 73-74. Amnesty goes on to say "armed groups defining themselves 'Islamic groups' often adopted similar patterns of conduct." $I d$. at 73.

177. Mamoun Fandy \& Dana Hearn, Egypt: Human Rights and Governance, in Middle EAST and North Africa: Governance, Democratization, Human Rights, supra note 164, at 103, 121. 
While Algeria has been in a state of emergency since 1992, Egypt has, with the exception of an 18 month period in the early 1980s, been under its own state of emergency since $1967 . .^{178}$ Egypt's apparent perennial state of emergency has been criticized by the UN Human Rights Committee, which maintains that states of emergency must be of an "exceptional and temporary nature and may only last as long as the life of the nation concerned is threatened." ${ }^{179}$ To that end, as a comment to the last report Egypt submitted to it in 1994, the Committee "expresses concern at the long duration of the state of emergency in Egypt" and that this state of emergency "constitutes one of the main difficulties impeding the full implementation of the Covenant." 180

The US Department of State noted that in Egypt, the ruling party, headed by the President Hosni Mubarak, "dominates the political scene to such an extent that citizens do not have a meaningful ability to change their government." ${ }^{\prime 181}$ This political exclusion is backed by the systematic repression of Islamic groups, including the Muslim Brotherhood, which has sought democratic reform while opposing violence. Amnesty International reports that "thousands of suspected members or sympathizers of banned Islamist groups ... were still held without charge or trial under emergency legislation following their arrest in previous years." 182 The same 1999 report goes further by indicating that trials of alleged members of Islamic groups before military and the Supreme State Security courts established as an emergency measure in 1997 continue "to be grossly unfair."183 The US Department of State reports that Egyptian security forces committed numerous serious human rights abuses, as they: "torture prisoners, arbitrarily arrest and detain persons, hold detainees in prolonged pretrial detention, and occasionally engage in mass arrests. In actions unrelated to the antiterrorist

178. See the Joint Press release by the Center for Human Rights Legal Aid and al-Hadim Center for the Management and Rehabilitation of Victims of Violence, 30 Years of Emergency Law: Has it ended the violence? 24 Feb. 1997, on file with author.

179. Derogation of Rights (Art. 4), General Comment No. 5, Hum. Rts. Comm., 13th Sess. II 3 (1981) available at <http://www.unhchr.ch/tbs/doc.nsf/Documentsfrset?OpenFrameSet>.

180. Consideration of Reports Submitted by States Parties Under Article 40 of the Covenant, Hum. Rts. Comm., 48th Sess. III 9 \& 7, U.N. Doc. CCPR/C/79/Add.23 (1993) [hereinafter Article 40 Reports].

181. U.S. Dept. of State, Bureau of Democracy, Human Rights, and Labor, Country Reports on Human Rights Practices-1999, II 4 (EGypt) (2000), available at <http://www.state.gov/g/ $\mathrm{drl} / \mathrm{rls} / \mathrm{hrrpt} / 1999 /$ index.cfm?docid=408> [hereinafter U.S. Dept. OF State, Country RePORTS].

182. Al, Amnesty International Report 1999 (Egypt) 154, 155. It has been estimated that this number of "Islamic" prisoners in early 1998 stood "at somewhere between 10,000 and 30,000, depending on the source." Instituto Del Turcer Mundo, The World Guide 1999/ 2000: A VieW FROM THE SOUTH 237 (1999).

183. Al REPORt (EGYPT), supra note 182, at 155. 
campaign, local police killed, tortured, and otherwise abused both criminal suspects and other persons." ${ }^{\prime 184}$

\section{c. Libya}

Although Libya suffered through much of the 1990s from an international pariah status resulting from UN Security Council sanctions that were brought on by its security forces' alleged involvement in the Lockerbie incident, "Libyans voice few calls for change."185 The lack of internal political dissent may in part be due to a higher standard of living enjoyed in Libya than in the other Northern states under review. ${ }^{186}$ However, it appears that dissent has also been systematically curtailed by the state, which seeks to limit the influence of Islamic groups clamoring for political participation and change. In a news article, Amnesty International was reported as stating:

Since the beginning of 1995 there have been numerous sporadic armed clashes between the Libyan security forces and members of armed Islamist groups. . . . Thousands of suspected Islamist activists of varying trends are said to have been arrested in the last few years, most of whom are still believed to be held without charge or trial. ${ }^{187}$

As Peter Woodward of Reading University has noted, opposition groups in Libya have coalesced under the banner of Islam "for it has become a theme of [Colonel Muammar El] Quaddafi's Libyan opponents, though he, having his own interpretation of Islam, sees no room for their criticism." 188 This intransigence was evident in June and July 1998, when "around 100 professionals, including engineers and university lecturers, were arrested on suspicion of supporting or sympathizing with al-Jama'a al-Islamiya al Libiya (Libyan Islamic Group) an underground Islamist movement which was not known to have used or advocated violence."189 Targeting Islamic groups is not a new theme in Libya. Amnesty International records that five individuals

184. U.S. Dept. of State, Country Reports, supra note 181.

185. Mohamedou, supra note 167 , at 221.

186. Libya ranks sixty-fifth on the Human Development Index, a United Nations Development Program index which takes into consideration such factor as life expectancy, adult literacy rates, education levels, and real GDP to give a ranking of states. Algeria ranks 109, Egypt 120, and Tunisia 102. See United Nations Development Program, Human Development Report 1999, available at <http://www.undp.org/hdro/HDI.html>.

187. Libya: No chance for dissenting voices, Afr. News Service, 3 July 1998, MDE 19/08/98, available on Lexis-Nexis at <http://web.lexis-nexis.com/universe>.

188. Peter Woodward, Sudan: Islamic Radicals in Power, in Political Islam: Revolution, RADICALISM, OR ReFORM?, supra note 163, at 108.

189. Al, Amnesty International Report 1999 (Libya) 238. 
"who were arrested in 1973 and convicted of membership of the prohibited Islamic Liberation Party, continued to serve life sentences."190

The UN Human Rights Committee has expressed concerns relating to allegations of "systematic use of torture and cruel, inhuman and degrading treatment" and "extrajudicial, arbitrary or summary executions perpetrated by state agents as well as of a high incidence of arbitrary arrest and detention, including long detention without trial."191 Human Rights Watch reports that "the development of civil society remained hostage to punishing restrictions on the exercise of freedom of expression, assembly, and association." 192

\section{d. Tunisia}

Among the four North African states under consideration, Tunisia is the location "where human rights conditions and democratization have regressed the most since 1987"193 when General Zine Abidine Ben Ali conducted a "medical" coup to take over the presidency. MohammadMahmoud Mohamedou terms Tunisia a police state, where "Ben Ali has derived his power from control of the security forces and the specter of an Islamist state."194 This authoritarian regime manifests itself in "incessant surveillance, harassment, reprisals against family members, or imprisonment."195 Human Rights Watch reports that:

Suspected Islamist sympathizers continued to receive the harshest treatment. Actual or suspected members of the outlawed [Islamist] an-Nahdha movement remained in prison, in exile, or at liberty but subject to harsh restrictions and the whims of the local police. They continued to comprise the majority of Tunisia's political prisoners, estimated at between 1,000 and 2,000.196

The Human Rights Watch Report goes on to note restrictions, including denial of passports, requirements to sign in at police stations on a frequent basis, and such whims as house searches without warrant and imprisonment on "trumped-up charges." 197

190. Id.

191. Report of the Human Rights Committee, U.N. GAOR, 54th Sess., Supp. No. 40, III 127 \& 130, U.N. Doc. A/54/40 (1999).

192. Human Rights Watch, Middle East and North Africa Overview, in Human Rights Watch WORLD REPORT 2000, II 3 (2000) available at <http://www.hrw.org/wr2k/>.

193. Mohamedou, supra note 167 , at 231.

194. Id. at 234.

195. Human Rights Watch, Middle East and North Africa Overview (Tunisia), in Human Rights WATCH WorLD RePORT 2000, II 1 (2000) available at <http://www.hrw.org/wr2k/> (visited 19 Nov. 2001) [hereinafter Tunisia Overview].

196. Id. at $\mathbb{I I} 1$.

197. Id. at II 2. 
While Tunisia has been "entirely free of political violence for several years," the authorities see this lack of violence as a justification for maintaining their draconian system of authoritarianism which has been in place since "a massive crackdown in 1991-1992."198 As a result, freedom of expression has been severally restricted, as "Tunisia's television, radio, and daily press exhibited no independence when it came to examining government policies." 199 Even specific editions of the French newspapers Le Monde and Libération "were banned during the first half of 1999."200

Beyond severe restrictions on the press, the UN Committee against Torture (CAT), ${ }^{201}$ has expressed its concern that there exists in Tunisia a "wide gap between law and practice with regards to the protection of human rights." ${ }^{202}$ The CAT singles out torture by noting that it is "disturbed by the reported widespread practice of torture' . . . perpetrated by security forces and police." ${ }^{\prime 203}$ The CAT noted that regulations on detention were not followed, thus leading to abuse, and that a climate of impunity had been established. The CAT stated that "by denying these allegations, 'the authorities are in fact granting those responsible for torture immunity from punishment, thus encouraging the continuation of these abhorrent practices.'" 204

\section{B. Transgressions of Human Rights in Southern Africa}

\section{General}

In contrast to the human rights violations of North African states, those that characterize the Southern region cannot be encapsulated into a single religious or political theme. While forms of civil strife persist in Angola, Swaziland, and Zambia, each state possesses its own unique political context and constitutional framework. ${ }^{205}$ In Lesotho and Namibia, civil conflict has sprung up and simmered down, while in other states, recent

\footnotetext{
198. Id. at II 13.

199. Id. at II 3 .

200. Id. at II 18.

201. The UN Committee against Torture is the body established to monitor the adherence of the state parties to the Convention against Torture and other Cruel, Inhuman and Degrading Treatment of Punishment.

202. Tunisia Overview, supra note 195.

203. Id. at $\mathbb{I I} 6$.

204. Id.; see also Human Rights Watch, The Administration of Justice In Tunisia: Torture, Trumpedup Charges and a Tainted Trial (Mar. 2000), available at <http://www.hrw.org/reports/ 2000/tunisia/> (visited 18 Nov. 2001) [hereinafter TUnIIIA: TORTURE].
}

205. See supra pages 98-103. 
transition to democracy has shown early signs of success and human rights violations have sometimes had little if any political explanation at all. Zimbabwe is one of the older emerging democracies in Southern Africa, but human rights violations have threatened the very survival of the pillars of that democracy, although there is no civil war in progress. In the absence of civil war, breaches of human rights have generally either served to curb opposition, principally through infringements of the right to freedom of expression, or merely demonstrate the fledgling nature of developing democratic institutions, as is the case with police brutality and poor prison conditions.

\section{State Specific Situations}

\section{a. Angola}

A protracted war has reigned in Angola since negotiations for its independence were inaugurated in 1974. The Alvor Agreement of 1975, which envisaged a coalition transitional government, failed in its objective when certain parties attempted to acquire power by force. One of them, the MPLA, declared independence and took control of the country. However, its main opponent the National Union for the Total Liberation of Angola has waged a civil war with ruthless persistence. ${ }^{206}$ Peace agreements in 1991 and 1994 failed to put an end to the war. The latter agreement was partially successful disarming UNITA rebels ${ }^{207}$ and incorporating leaders into government positions, ${ }^{208}$ but the main opposition leader, Jonas Savimbi, resumed hostilities that continue despite a UN arms embargo against UNITA. ${ }^{209}$

This civil war has been accompanied by wide ranging human rights abuses, including indiscriminate aerial bombings, torture, disappearances, summary executions, looting, rape, internal displacement of civilians, killing of civilians, and the recruitment of child soldiers. ${ }^{210}$ Since the complete resumption of hostilities in December 1998, freedom of expression and of the press have been suppressed by both sides of the conflict

206. See The Statesman's Yearbook: 1998-1999 110-11.

207. See Tazuary Nkeita, Angola: Rebuilding Confidence, SAPEM, Feb. 1995, at 16.

208. See Statesman's Yearbook, supra note 206.

209. See S. Afr. Rep., 17 Jul. 1998, at 7-8; Angola: All About Power, Afr. Confidential, 5 Feb. 1999, at 4-5; Angola II: Deadly Diamonds, Afr. Confidential, 16 Apr. 1999 at 5-6.

210. See Al, Amnesty International Report 1997, 1998 \& 1999 (Angola); see also Al, Angola: Civilians Tortured and Killed in Cabinda's Forgotten War, Amnesty InTERnAtIOnal (News ReleAsE), 29 Apr. 1998, Al Index: AFR 12/004/1998, available at <http://web.amnesty.org/ ai.nsf/Index/AFR120041998>; AI, Angola: Unarmed Civilians Caught in the Spiral of Violence, Amnesty International (News Release), 14 Dec. 1998, Al Index: AFR 12/009/1998, available at <http://web.amnesty.org/ai.nsf/Index/AFR120091998>. 
through violence and legal arrests of and legal proceedings against journalists. UNITA has been particularly radical in its disregard for freedom of expression. Amnesty International has also remarked that in "UNITA controlled areas freedom of expression is practically non-existent." 211 The civil war has also dealt human rights a special blow that sets Angola apart from its neighbors in that social and economic rights lost all meaning for parts of its population. A recent $U N$ report reveals that people are surviving on "larvae and grass" in parts of Angola's central province. ${ }^{212}$

\section{b. Swaziland}

While civil war persists in Angola, other states have failed to respect the human rights of their citizens as part of an effort to keep a tight hold on the reins of power. Swaziland has been in a state of emergency since 1973 when the constitution was suspended. Political activity is banned and freedom of expression and assembly are restricted. On the positive side, in contrast to some other southern African states, Swaziland has shown a modicum of respect for press freedom. In 1998, it held back on plans to introduce tough media legislation in favor of allowing journalists to establish their own self-regulating media council. ${ }^{213}$ Southern Africa Report notes, ironically, that: "Swaziland appears to be the only southern African state outside South Africa that has come to recognize that the promotion of media freedom should be an intrinsic part of its transformation to a democratic society." 214

Paradoxically, opposing voices are suppressed in other ways. Demonstrations have been violently quelled with the use of tear gas, batons, sjamboks (a form of traditional whip), and live ammunition. ${ }^{215}$ Amnesty International regularly reports allegations of mistreatment including torture of detainees by the police..$^{216}$

Beyond such limitations, there have been notable examples of disregard for democratic process and the rule of law. In 1997, the Acting Chief Justice was dismissed from this post after ordering the release of detainees held illegally. ${ }^{217}$ In 1999, two days before parliamentary elections, soldiers and

211. Al, Angola: Targeting of Journalists, Amnesty InTERNATIONAL (News ReleAse), 10 Nov. 1999, at 1, Al Index: AFR 12/004/1999, available at <http://web.amnesty.org/ai.nsf/Index/ AFR120041999>.

212. See Lara Pawson, UN: Angola is on the brink, BBC News, 26 Apr. 2000, available at <http://news6.thdo.bbc.co.uk/hi/english/world/africa/newsid_726000/726387.stm>.

213. See Swaziland defers tough media legislation, S. Afr. Rep., 24 Apr. 1998, at 7-8.

214. Id.

215. See Al, Amnesty International Reports 1997, 1998 (Swaziland).

216. See generally Al, Amnesty International Reports 1997, 1998 \& 1999 (Swaziland).

217. See Al, Amnesty International Report 1997 (Swazlland) 297. 
armed police invaded the homes of members of the opposition party, the Swaziland Democratic Alliance, looking for papers calling for a boycott of the elections. ${ }^{218}$ Africa Confidential reported in 1999 that in response to an incident where a bomb had been placed under a bridge over which the king had just passed, the government passed the Swazi Administration Order. This order apparently gave 200 chiefs the authority to arrest and to try suspects without warrants or legal representation and made those chiefs subject to fines or dismissal if they failed to prohibit conduct that may cause riots or disturbances. ${ }^{219}$

\section{c. Zimbabwe: Unofficial One Party State in Democratic Clothing}

Zimbabwe is another leading example of a state with an insecure government infringing its citizens' rights in order to maintain power. Unlike Swaziland, Zimbabwe possesses a functioning democratic constitution, but the fact that the ruling ZANU-PF party possesses 147 out of the 150 seats in parliament smacks of a one party state. 220 The media has not only been tightly controlled but oppressed. In 1998, reports indicated that the government was planning legislation to prevent a foreign media consortium from launching newspapers in Zimbabwe. ${ }^{221}$ In 1999, the government instructed the state-owned media to refrain from reporting on the organization of a strike against tax and price rises for staple foods. ${ }^{222}$ In the same year, there were reports of the arrest and torture of journalists. ${ }^{223}$ It is said that several years ago President Mugabe openly exclaimed in response to a question as to why he did not allow a second privately owned TV station, "What! And allow my opponents to gain a political platform. Certainly not!" 224

The clampdown on the press has been accompanied by restrictions on freedom of association and the unnecessary use of teargas on peaceful demonstrators. Minority groups have also been the focus of attack in an apparent attempt to gain popularity with the majority. Homosexuals have been particular subjects of discrimination, as demonstrated by the

218. See Al, Amnesty International Report 1999 (Swaziland) 317.

219. See Swaziland: King's Move, Afr. Confidential, 16 Feb. 1999, at 8.

220. Robert Mugabe, Zimbabwe strongman, BBC News, 15 Feb. 2000.

221. See Zimbabwe Plans to Curb New Media Group, S. Afr. Rep., 31 July 1998, at 11-12.

222. See Al, Amnesty International Report 1999 (Zimbabwe) 370.

223. See Al, Press Freedom in Zimbabwe, Amnesty International (News Release), 13 Jan. 1999, Al Index: AFR 46/01/99, available at <http://web.amnesty.org/ai.nsf/Index/AFR460199>; Al, Zimbabwe: Fears for Newspaper Director High, Amnesty International (News Release), 22 Jan. 1999, Al Index: 46/04/99, available at <http://web.amnesty.org/ai.nsf/Index/ AFR460041999>.

224. Zimbabwe Plans to Curb, supra note 221, at 12. 
government's attempt to ban a gay and lesbian organization from participating in Zimbabwe's international book fair, ${ }^{225}$ and President Mugabe's open criticism of homosexuals. For example, President Mugabe castigated the World Council of Churches for admitting homosexuals to their general assembly in Harare, and on another occasion, stated that the constitution guaranteed freedom "except for gays." 226

White farmers have also been beaten, killed and evicted from their farms by so-called "war veterans" with the apparent support of the president. ${ }^{227}$ These incidents and others have demonstrated the leader's total disrespect for the rule of law where the courts have intervened and the court orders deliberately flouted by the president and the law enforcement agencies. Earlier in 1999, military officials defied three high court rulings requiring the release of a journalist from army detention, and on the Supreme Court requesting the president to reaffirm commitment to the rule of law, the president retorted with a request for the resignation of the justices. ${ }^{228}$

\section{d. Lesotho and Zambia: Democratic Institutions Without Democracy}

In Lesotho and Zambia the basic pillars of democracy are in place but there remain politically motivated violations of human rights. Institutionally, Lesotho is a democratic monarchy and Zambia a democratic republic. Zambia was an official one-party state from 1964 to 1991. This political system was abandoned in 1991 due to severe economic problems, ${ }^{229}$ but a culture of human rights violations has persisted. Both countries have been characterized by a lack of respect for the free media, incidents of torture, and unlawful killings by the police, as well as harsh prison conditions. ${ }^{230}$ Journalists critical of the respective governments and political opponents alike have been the subjects of harassment and attack in these countries. In 1998 in Lesotho, an army insurrection followed by a badly managed intervention by South African and Botswana troops exacerbated the poor

225. See Al, Amnesty International Report 1997 (Zimbabwe) 347.

226. Al, Amnesty International Report 1999 (Zimbabwe) 371.

227. See Zimbabwe: The Mess One Man Makes, Economist, 22 Apr. 2000, at 18.

228. See Al, Zimbabwe: Government Crack-down on Civil Society, Amnesty International (News Release), 8 Feb. 1999, at 2, Al Index: AFR 46/08/99.

229. See Minnie Venter \& Tapfumaneyi Eliot Manyika, Democratization and the Impact on Critical Issues, in Prospects for Progress: Critical Choices for Southern Africa 60, 66-67 (Minnie Venter ed., 1994).

230. See Human Rights Watch, Human Rights Watch Report 2000 (Zambia), available at <http:// www.hrw.org/wr2k/>; Al, Amnesty International Reports 1997, 1998 \& 1999 (Lesotho); Al, Amnesty International Reports 1997, 1998 \& 1999 (Zambia). 
human rights situation. ${ }^{231}$ Given the political nature of abuses, it is difficult to attribute to the ruling parties of these states a bone fide intention to promote human rights.

\section{e. Botswana, Malawi, Mozambique, Namibia, and South Africa: Generally Peaceful and Emerging Democracies}

In Botswana, Malawi, Mozambique, Namibia, and South Africa, peace generally reigns and democracy functions: political parties can freely compete for power; there is respect for the independence of the judiciary; and the governments can be attributed with an intention to respect human rights, at least within their own jurisdiction. These governments are, for the most part, not willing accomplices to abuses. Those abuses that occur are, in so far as they are attributable to organs of the state, not part of an official or unofficial government policy but rather are linked to the various social and cultural factors related to their status as emerging democracies.

Most of these states have fledgling democratic frameworks. Malawi's multiparty democracy dates back to 1994, Mozambique's to 1993, Namibia's to 1990, and South Africa's to 1994. Botswana's democracy has been developing steadily for some thirty years, a record on a continent familiar with regular change. Minnie Venter and Tapfumaneyi Eliot Manyika have identified seven reasons for Botswana's success including:

- The issues in Botswana's post-colonial politics—unlike those in many other African states-have not produced controversial or explosive situations.

- Cleavages, particularly ethnic rivalries, have not been so deep as to affect political stability.

- Conflicts have been manageable.

- The ruling party incorporated the traditional authority of the chiefs.

- Economic prosperity and the fairly equitable distribution of scarce resources to a small population have enabled the government to contain discontent.

- Independence and liberation did not follow a bloody struggle as in many other African states, for example, Zimbabwe, Mozambique and South Africa.

231. See Lesotho Burns as South African Soldiers Put Down Coup and Restore Order: 10 People Killed, S. Afr. Rep., 25 Sept. 1998; Al, Lesotho: Response to Crisis Should be Demilitarised and Human Rights Respected, Amnesty International (News Release), 30 Sept. 1998, Al Index: AFR 33/003/1998, available at <http://web.amnesty.org/ai.nsf/Index/ AFR330031998> (visited 18 Nov. 2001). 
- Continuing majority support for the ruling party has meant there has been no motive to declare a one-party state as a way of ousting a competitor. ${ }^{232}$

However, regular serious human rights violations continue to take place in the territories of these states. Human rights observers have reported poor prison conditions and ill treatment, killings, and torture by the police. ${ }^{233}$ Additionally, South Africa has seen extreme acts of xenophobia ${ }^{234}$ and Botswana has imprisoned homosexuals. ${ }^{235}$ Given the intensity of the struggle for human rights in South Africa and the international condemnation of apartheid, there may have been legitimate expectations that the new government would take the high moral ground on issues of human rights violations in foreign states. A contemporary observer and political analyst of the election period of 1994, John Daniel, remarked that "given the recent reprehensible events in the country, South Africa's future foreign policy, at least at the rhetorical level, will have a strong human rights dimension."236

Yet, South Africa failed to condemn strongly Zimbabwe's encouragement of the invasion and pillage of white owned farms and its disregard for the rule of law. There are of course other political motivations for saving the face of one's African neighbors, including the similar struggles of the past, issues of loyalty, ${ }^{237}$ and the existence of identical issues within one's own jurisdiction that could potentially also get out of hand. South Africa's land issues are no less contentious, but the state has no doubt for economic reasons, taken few serious steps towards land redistribution. ${ }^{238}$

Recent interventions in neighboring states have done little to demonstrate a united determination to promote human rights. The intervention of troops from Botswana and South Africa in the Lesotho crisis, far from pacifying the population, ignited a burst of violence. Some of these foreign troops were accused of, inter alia, using excessive force, raping local

232. Zimbabwe: Government Crack-down, supra note 228, at 66-67.

233. See Al, Amnesty International Reports 1997, 1998, and 1999 (Botswana, Malawi, Mozambique, Namibia, and South Africa).

234. See Tangeni Amupadhi, African foreigners terrorised, Mall \& Guardian, 18-23 Dec. 1998; Ann Eveleth, Rights groups slam "xenophobic" official, Mall \& Guardian, 5-11 Nov. 1999.

235. See Al, Amnesty International Report 1997 (Botswana).

236. John Daniel, South Africa's Role in the Changing World and its Impact on the Region, in Prospects for Progress: Critical Choices for Southern Africa 28, 33 (Minnie Venter ed., 1994).

237. President Mugabe was one of the front line advocates for comprehensive regional sanctions against South Africa. See Christine Sylvestor, Zimbabwe: The Terrain of Contradictory Development 170-72 (1991).

238. Although land has been redistributed where its past owners had been forcibly removed during the apartheid era. 
women, and looting. ${ }^{239}$ The Angolan government has reportedly recruited Namibian children for the war with the apparent acquiescence of Namibia. ${ }^{240}$

Southern African states therefore fall into differing categories of human rights situations, but none of them have sufficiently clean hands that they can mount a moral crusade against others. Various other political factors, some of which have been mentioned, further militate against this approach. A genuine common determination in this regard would require some level of admission of failure, which does not come easy for governments that have to appease populations that suffer from serious social setbacks. High rates of crime and poverty as well as astronomical AIDS statistics attack the social infrastructure of most Southern African states and provide little hope that governments will get a firm handle on human rights problems. ${ }^{241}$

\section{CONCLUSION}

This study of the North and Southern African states reveals that African unity, where it relates to human rights law and practice, exists in the first instance in an ephemeral manner and, in the second, as against the promise entailed by the African Charter. These states have united in rhetorical support through treaty participation. They have also united in their failure to implement these same rights. There exists no unity of purpose on the African continent when it comes to undertaking international human rights obligations; further, the extent of constitutional incorporation of such norms and the bona fides of implementation of their international obligations is a patchwork of consistency and variance.

North Africa differs from Southern Africa by making notable reservations to human rights treaties that subject its international obligations to religious norms and paralyze the enforcement mechanisms envisaged by the treaties; "states of emergency" then place these states within a different and supposed exceptional normative framework. While the Northern states generally consider their human rights obligations to form automatically part of their domestic law, this occurrence is less a result of a deliberate policy than of their approach to treaties generally, as derived from past practices of their former colonial power. A commitment to endorsing human rights in the domestic normative framework is hardly reflected in the constitutional provisions of these states.

239. See, e.g., Al, Response to Crisis Should be Demilitarized and Human Rights Respected, Amnesty International (News Release), 30 Sept. 1998, Al Index: AFR 33/003/1998; Lesotho Intervention Snippets, S. Afr. Rep., 9 Oct. 1998.

240. See Namibia Gives MPLA a Platform for Attack, S. Afr. Rep., 7 Jan. 2000.

241. See Zimbabwe: Crack-down, supra note 228, at 32-36. 
In contrast, the states in Southern Africa do not generally automatically embrace all treaties into the domestic arena but have, for the most part, given fairly detailed expression of human rights obligations in constitutions. It is at the level of conscious respect that the clearest divergence among Southern states exists. Some governments have respected the basic principles of democracy by generally refraining from state sponsored violations. This restraint does not exist in Angola, Lesotho, Swaziland, Zambia, and Zimbabwe, all of which willingly violate rights at varying degrees of intensity. The Northern states under review have, likewise, all been active participants in the denigration of a human rights culture.

Ultimately, where all the African states under review unite, and this is the sad reality, is simply at the levels of rhetoric and abuse. The move towards establishing the African Court of Human and Peoples' Rights is a means of staying these tides by holding all African states to the same standards. If African unity means anything today, should it not mean that Africans from coast to coast have the inherent dignity to enjoy life on their continent without fear of violations to their African Charter rights? An African court holds out the promise that states will be held responsible for violation of the African Charter and that the continent can bridge the gaps that clearly exist between the peoples of North and Southern Africa through the union of common human rights standards. 